\title{
A history of the biogeography of Amazonian fishes
}

\author{
Fernando C. P. Dagosta ${ }^{1,2}$ and Mário C. C. de Pinna ${ }^{2}$
}

The history of knowledge about Amazonian biogeography is as rich as its fish community, and a fascinating theme of study in itself. Several current paradigms and controversies about Amazonian fish biogeography are rooted in principles dating from the second half of the $18^{\text {th }}$ to the first half of the $19^{\text {th }}$ centuries. The present work establishes a relationship between current biogeographical ideas and their old predecessors, on the basis of a chronologically-oriented historical continuity analysis. The advent of evolutionary theory has not contributed significantly to a transformation of the knowledge on the biogeography of Amazonian fishes. On the other hand, the two main schools of biogeographical thought (dispersalist and vicariant) had major implications on how Amazonian fish distribution is interpreted. The process was gradual and many hypotheses have combined elements from each of the two schools. Chronologically, practically the entire tradition of Amazonian biogeography takes place within the evolutionary paradigm, although its founder Louis Agassiz was himself an anti-evolutionist. The birth of Amazonian biogeography is Agassiz's travel in Amazon. That document makes it clear that the author did not consider dispersal as a valid explanation for the biogeographical patterns he found. Later, Carl Eigenmann helps to spread the dispersalist tradition as a model for biogeographical explanations in fish distributions, a phase which lasted until the late $20^{\text {th }}$ century. A major shift occurs with the contributions of Marylin Weitzman, Stanley Weitzman and Richard Vari, who associated the temporal framework of phylogenetic hypotheses with distribution patterns, underscoring the predictive power of vicariant biogeography. The present-day paradigm begins with the work of John Lundberg and attempts to incorporate geomorphological and phylogenetic information into integrative biogeographical hypotheses. Some emblematic problems have delayed proposition of general hypotheses on the phylogenetic biogeography of South American fishes, such as the poor state of knowledge of their species-level systematics; an incomplete distributional record for most species and sparse or non-existent data on the phylogenetic history of most supraspecific taxa. Such drawbacks are now being corrected at a fast pace. Recent advances on geographical distribution and an increasing number of phylogenetic hypotheses will allow unprecedented large-scale biogeographic analyses, including those based on event models and Bayesian inference. Thus, the biogeography of South American fishes, especially Amazonian ones, should soon experiment a new age of progress. The success of that new phase will depend on its ability to recognize and segregate multiple overlapping temporal layers of hydrological changes, and to develop analytical tools that can deal with temporal mixing.

Keywords: Amazon, Biodiversity, Ichthyology, Neotropical, South America.

A história do conhecimento da biogeografia amazônica é tão rica quanto sua comunidade de peixes e um tema fascinante de estudo em si. Vários paradigmas e controvérsias atuais sobre a biogeografia de peixes amazônicos estão enraizados em princípios que datam da segunda metade do século 18 até a primeira metade do século 19 . O presente trabalho estabelece uma relação entre as idéias biogeográficas atuais e seus antecessores antigos a partir de uma análise histórica cronologicamente orientada. O advento da teoria evolutiva não contribuiu significativamente para a transformação do conhecimento sobre a biogeografia dos peixes amazônicos. Por outro lado, as duas principais escolas de pensamento biogeográfico (dispersalista e vicariante) tiveram grandes implicações sobre a interpretação da distribuição de peixes amazônicos. O processo foi gradual e muitas hipóteses combinaram elementos de cada uma das duas tradições. Cronologicamente, praticamente toda a história da biogeografia amazônica ocorre dentro do paradigma evolutivo, embora seu fundador Louis Agassiz fosse ele próprio um anti-evolucionista. O nascimento da biogeografia amazônica é o relatório de viagem de Agassiz na Amazônia. Esse documento deixa claro que o autor não considerou o dispersalismo como uma explicação válida para os padrões biogeográficos que encontrou. Mais tarde, Carl Eigenmann ajuda a disseminar a tradição dispersalista como modelo para explicações biogeográficas na distribuição de peixes, uma fase que perdurou até o final do século 20. Uma grande mudança ocorre com as contribuições de Marylin Weitzman, Stanley Weitzman e Richard Vari, que associaram a dimensão temporal de hipóteses filogenéticas com padrões de distribuição, revelando o poder preditivo da biogeografia vicariante. O paradigma atual começa com o trabalho de John Lundberg e busca incorporar informações geomorfológicas e filogenéticas em hipóteses biogeográficas integrativas. Alguns problemas emblemáticos atrasaram a proposição de hipóteses gerais sobre a biogeografia vicariante de peixes da América do Sul, como o mau estado de conhecimento de sua sistemática em nível de espécie; o registro de distribuição geográfica incompleto para a maioria das espécies e dados es-

${ }^{1}$ Faculdade de Ciências Biológicas e Ambientais, Universidade Federal da Grande Dourados, Rodovia Dourados - Itahum, Km 12 - Cidade Universitária, 79804-970 Dourados, MS, Brazil. ferdagosta@gmail.com, @ittp://orcid.org/0000-0001-7163-296X (corresponding author)

${ }^{2}$ Museu de Zoologia da Universidade de São Paulo, Avenida Nazaré, 481, Ipiranga, 04263-000 São Paulo, SP, Brazil. pinna@ib.usp.br 
cassos ou inexistentes sobre a história filogenética da maioria dos táxons supraespecíficos. Essas desvantagens agora estão sendo corrigidas em um ritmo acelerado. Avanços recentes na distribuição geográfica e um número crescente de hipóteses filogenéticas permitirão inéditas análises biogeográficas de grande escala, inclusive aquelas baseadas em modelos de eventos e inferência bayesiana. Assim, a biogeografia dos peixes sul-americanos, especialmente os amazônicos, deve experimentar em breve uma nova era de progresso. O sucesso dessa nova fase dependerá de sua capacidade de reconhecer e segregar múltiplas camadas temporais sobrepostas de mudanças hidrológicas e desenvolver ferramentas analíticas que possam lidar com a mistura temporal.

Palavras-chave: Amazonas, América do Sul, Biodiversidade, Ictiologia, Neotropical.

\section{Introduction}

For centuries, explaining the geographical distribution of faunas has been an enticing subject for scientists and the Amazonian biota stands out as a most daunting challenge among them. The Amazon basin has the most diverse fish fauna on Earth, with myriad evolutionary lineages resulting from interactions of a multitude of geological processes dating back to Gondwana (cf. Ribeiro, 2006; Dagosta, de Pinna, 2017). It includes extremely ancient lineages acquired by former continental connections, such as Osteoglossiformes, Characiformes, Siluriformes and Dipnoi, in addition to tens of species derived from marine ancestors which invaded the freshwater environment, as Potamotrygonidae, Tetraodontindae, Belonidae and many others. The largest parcel (over $80 \%$ ) of the Amazonian ichthyofauna, however, belongs to three orders of the series Otophysi, namely Characiformes, Siluriformes and Gymnotiformes. In addition to its sheer vastness in area, the Amazon basin includes various distinct physiognomies, formed by the widely divergent terrain and geological backgrounds. In turn, this diversity is associated with a diversity of vegetation types, rivers and soils (cf. Goulding et al., 2003).

The history of knowledge about the Amazonian biota is as rich as its fish community and geomorphology, and a fascinating theme of study in itself. This information, however, is scattered throughout a multitude of sources covering several centuries and which has rarely been the object of synthetic organization and analysis. The understanding of the biogeography of Amazonian fishes has changed over the years and compose a rich scenario against which one can appreciate shifting paradigms in biogeographical theory. Some modern hypotheses about the biogeography of Amazonian fishes can be traced back to traditions from the second half of the $17^{\text {th }}$ century to the first half of the $19^{\text {th }}$. In this paper, we offer an analytical narrative of the evolution of our understanding of the biogeography of Amazonian fishes. Our aim is to offer both an organized picture of that history and also to connect its main features with advances in the broader subject of historical biogeography. As will be seen, changes in our understanding of Amazonian fish distribution reflect major shifts in the development of biology, but not always in synchronized fashion.

\section{Material and Methods}

We employ the Historical Method, i.e., trying to understand the major stages of taxonomic and biogeographic investigation on Amazonian fishes in causal sequential rela- tion to preceding ideas about the same phenomena. We try to connect observed patterns with then-prevailing paradigms on evolution and biogeography. All pertinent literature is revised without a priori judgment about their current validity, as an attempt to understand their intrinsic significance in their own historical context. Only after that we proceeded to analyze them according to subsequent, and finally current, standards. Our sequence of presentation is broadly chronological and is divided in sections which reflect major historical periods. However, some specific contributions are discussed in the thematically-related section.

The distinction between concepts of dispersal and dispersion follows Platnick (1976). Natural movement of individuals within the natural range of a taxon is considered dispersion, while dispersal refers to the original meaning by Buffon, i.e., movement of a taxon outside of its natural range (Nelson, 1978).

\section{Results and Discussion}

Discovery of the new world and the dawn of taxonomy $\left(16^{\text {th }}\right.$ to $18^{\text {th }}$ centuries). The earliest reports on the fishes of the Amazon were made by travelers-explorers of the $16^{\text {th }}$ century, whose mission was to report to their rulers on the natural resources in the region. They provided only very general information about the existence of fishes, their abundance and their use by local people. Reports at that period are in the form of letters written by explorers of their own accord, and fishes are mentioned in passing as part of broader accounts on their travel experiences in the Amazon (Pereira, 2003). Documents from this period were not intended as scientific and their authors did not have specific academic background. Expectedly, reports from the $16^{\text {th }}$ century did not have a significant impact on the knowledge of Amazonian ichthyology (Pereira, 2003). The Portuguese Diogo Nunes was the first individual ever to record any observations on Amazonian fishes. Nunes was part of the expedition led by Alonso Mercadillo to the Río Marañon and his observations were included in a letter of 1553 or 1554 to King D. João III of Portugal. His report informs that the expedition went from the Río Huallaga to the Río Marañon and then on to the rio Solimões, reaching in 1538 an area located between today's Brazilian cities of Tefé and Coari, Nunes writes that fishes in that region are abundant and very diverse, being used in dried form as currency among natives (Papavero et al., 2000, 2002). Interestingly, his travel predate the trip of Francisco de Orellana (of 1542), commonly considered as "discoverer" of the Amazon. 
The acting chaplain of Orellana's expedition was Friar Gaspar de Carvajal. He recorded some reminiscences of the trip along the lower rio Madeira, lower rio Negro and the rio Amazonas, including references to fish on seven different occasions (Papavero et al., 1999, 2000, 2002; Pereira, 2003). All such instances are vague, only making reference to the existence of fish as foodstuff. One passage refers to a five-span fish caught by hook and line, but no details are included. The sparse list of $16^{\text {th }}$ century authors on Amazonian fishes includes also Francisco Vásquez, a navigation professional who took part in the expeditions of Pedro de Ursúa and Lope de Aguirre along the rio Negro and rio Solimões. As his predecessors, Vásquez makes only vague references to the abundance and culinary qualities of the fish in the region, without any observations which might provide technical information.

In the $17^{\text {th }}$ century, attention of European naturalists was focused on the novelties arriving from territories dominated by Spain and Holland in the New world (Günther, 1880). The first - and only pre-Linnean - naturalist to offer accurate accounts of the South American ichthyofauna was George Marcgrave who visited Brazil as physician with the expedition of Count Maurits of Nassau with Willem Piso. Marcgrave died in Africa and his manuscripts and drawings were published by Piso in Marcgrave (1648). Myers (1964) regarded Marcgrave as "the most important early work in the fauna and flora of America (p. 35)". Marcgrave (1648) includes illustrations of many specimens which cannot be identified to species level, but which nonetheless represent taxa that may possibly be Amazonian. The only species that can be indisputably be identified to species level in Marcgrave (1648) and which also occurs in the Amazon is Callichthys callichthys (Linnaeus, 1758).

The first species occurring in the Amazon were formally described by naturalists who never visited the region (Pereira, 2003). Those species were described on the basis of specimens almost always collected in other regions but which also occur in the Amazon. Linnaeus (1758) was the first to describe Amazonian fish species (Anostomus anostomus, Charax gibbosus, Astyanax bimaculatus, Gasteropelecus sternicla, Aspredo aspredo, Callichthys callichthys, Acanthodoras cataphractus, Loricaria cataphracta, Gymnotus carapo, Cichlassoma bimaculatum, Crenicichla saxatilis and Achirus achirus), none of those occurring exclusively in the Amazon. Most of the South American fish species of commercial importance were described until the second half of the $19^{\text {th }}$ century, all of which by European naturalists (Böhlke et al., 1978).

The first naturalists and the founding of Amazonian fish biogeography (end of $18^{\text {th }}$ and $19^{\text {th }}$ centuries). According to Myers (1947), the first naturalist to actually collect fishes in the Amazon was Alexandre Rodrigues Ferreira, who led a philosophical voyage (1783-1792) intended to provide an inventory of the peoples, places and natural objects encountered in Brazil, then within the domain of the Portugue- se crown (Akerman, 2009). Many specimens were superbly illustrated, but the material did not result in publications in the short term. Most specimens were seized in 1808 on the occasion of the invasion of Portugal by Napoleonic troops headed by Junot (Vanzolini, 1996) and sent to France. Part of the stolen material was examined by Etienne Geoffroy Saint-Hilaire and his son Isidore Geoffroy Saint-Hilaire, but no fish were described by those authors. It was only many years later that Cuvier and Valenciennes wrote scientific reports based on that material (e.g. Cuvier, 1819, 1829; Cuvier, Valenciennes, 1846), describing some of the most iconic Amazonian fish species, such as Colossoma macropomum (Cuvier, 1816), Hydrolycus scomberoides (Cuvier, 1819), Osteoglossum bicirrhosum (Cuvier, 1829), Piaractus brachypomus (Cuvier, 1818) and Vandellia cirrhosa Valenciennes, 1846.

The work of Linnaeus (1758) triggered other European naturalists (e.g. Bloch, Cuvier, Heckel, Kner, Lacepède, Müller, Valenciennes) to start describing fishes from the New World and a growing number of Amazonian species is published in that wake until the mid- $19^{\text {th }}$ century. The origin and early development of ichthyology is almost entirely European (Myers, 1964) and the first North American contribution to Amazonian fishes is Gill (1858) who describes some species occurring in the basin (Corydoras aeneus, Hemigrammus unilineatus, and Odontostilbe pulchra), but on the basis of species collected on the Island of Trinidad (= Trinidad and Tobago). The first solid North American contribution to the taxonomy of Amazonian fish fauna only comes with Cope (1870), who describes several species from the Upper Amazon.

The vast majority of authors from this period never set foot in the Amazon. One notable exception was the expedition of German naturalists Johann Baptist von Spix and Carl Friedrich von Martius to Brazil in 1817, part of the Austrian Mission. They traveled to Brazil along with a team of other scientists accompanying the Austrian Archduchess Caroline Josepha Leopoldine von Habsburg-Lothringen, on her way to marry then prince D. Pedro de Alcântara (later Emperor Pedro I of Brazil). Supported by the Portuguese crown, the two naturalists travelled through Brazil for two years collecting specimens, mainly from the Amazon. Spix returns to Europe after that period and prepares a series of plates of the fishes collected but dies before completing the publication. His work is then continued by Louis Agassiz in his Doctoral Thesis and finally published as Spix, Agassiz (1829-1831). A total of 52 species of South American and Amazonian freshwater fishes are described, including some of the most common and commercially important taxa, such as Prochilodus nigricans Spix, Agassiz, 1829; Schizodon fasciatus Spix, Agassiz, 1829; Brycon amazonicus (Spix, Agassiz, 1829); Serrasalmus nigricans (Spix, Agassiz, 1829); Rhaphiodon vulpinus Spix, Agassiz, 1829; Hoplerythrinus unitaeniatus (Spix, Agassiz, 1829); Boulengerella cuvieri (Spix, Agassiz, 1829); Pinirampus pirinampu (Spix, Agassiz, 1829); Astronotus ocellatus (Agassiz, 1831) and Cichla monoculus Spix, Agassiz, 1831. 
Among the entourage of Archduchess Leopoldine was also a young Johann Natterer, who stayed in Brazil for 18 years collecting specimens from a variety of organisms in the rivers Amazonas, Negro and Paraguay and in Southeastern Brazil (Böhlke et al., 1978). His material was sent to the Vienna Museum and served as basis for a series of descriptions of Amazonian cichlids by Jakob Heckel and of characiforms and siluriforms by Rudolf Kner. As pointed out by Böhlke et al. (1978), Natterer was the first explorer in South America who did not restrict his attention to large-sized species and his discovery of smaller components of the ichthyofauna represented a major breakthrough in the knowledge of the biodiversity in the continent. That fact, plus his attention to record precise locality data have set new and improved standards in the taxonomy of neotropical fishes.

Another naturalist who was in the Amazon during that period was Francis de Castelnau, who led an official scientific expedition by the French government to Brazil in 1843 to 1847. Castelnau (1855) describes several Amazonian fishes discovered during that trip, mainly siluriforms and cichlids (e.g. Brachyplatystoma rousseauxii, Liposarcus pardalis, Parancistrus aurantiacus, Pseudacanthicus spinosus, Crenicichla lacustris, Geophagus proximus, Mesonauta acora, Retroculus lapidifer and others). In that work, Castelnau compares the fish fauna of the Amazon with that of the La Plata basin: «Sous le rapport de la distribution géographique, je dirai qu'en général tous les poissons du bassin de l'Amazone me semblent différer spécifiquement de ceux des eaux de la Plata» (Castelnau, 1855: p. IV); «et que les poissons du bassin de l'Amazone semblent différer presque toujours de ceux qui habitent les affluents de la Plata» (Castelnau, 1855: X). Thus, Castelnau is one of the first scientists to recognize the pronounced faunistic differences between the Amazon and other South American drainages.

The most important naturalist to travel and collect in the Amazon in that period was Louis Agassiz, head of the famous Thayer Expedition (1865-1866). In Europe, Agassiz was one of the chief critics of Darwin's recently-published evolutionary theories. Agassiz believed that a research trip to study Amazonian fishes would reveal data to support his own creationist views. Reports of that trip were written by his wife and published in Agassiz, Agassiz (1868). Some authors criticize the superficiality of that narrative ( $c f$. Vanzolini, 1996), but the work is still a rich source of information and new ideas about Amazonian fishes. As noted by Böhlke et al. (1978), Louis Agassiz was the first to understand the immense magnitude of Amazonian ichthyofauna, especially among the small-size components. The total bewilderment and marvelous surprise before the vastness of Amazonian fish diversity is evident in several passages of Agassiz, Agassiz (1868): "You see that before having ascended the Amazons for one third of its course, the number of fishes is more than triple that of all the species known thus far, and I begin to perceive that we shall not do more than skim over the surface of the centre of this great basin" (Agassiz, Agassiz, 1868: letter to Pimenta-Bueno: 195). Agassiz was one of the greatest ichthyologists of his time and his appreciation of Amazonian fish diversity derived from a broad knowledge of other regions in the world: "I will not return to the surprising variety of species of fishes contained in this basin, though it is very difficult for me to familiarize myself with the idea that the Amazons nourishes nearly twice as many species as the Mediterranean, and a larger number than the Atlantic, taken from one pole to the other." (Agassiz, Agassiz, 1868: letter to the Emperor: 382); "Another side of this subject, still more curious perhaps, is the intensity with which life is manifested in these waters. All the rivers of Europe united, from the Tagus to the Volga, do not nourish one hundred and fifty species of fresh-water fishes; and yet, in a little lake near Manaos, called Lago Hyanuary, the surface of which covers hardly four or five hundred square yards, we have discovered more than two hundred distinct species, the greater part of which have not been observed elsewhere. What a contrast! (Agassiz, Agassiz, 1868: letter to the Emperor: 383).

Regardless of deeper ideological motivations of Agassiz at the beginning of his expedition, his bewilderment in face of Amazonian biodiversity unsettled him enough to incite reflections about the patterns of geographical distribution in South American fishes and their underlying causes: "Something is already known. It is ascertained that the South American rivers possess some fishes peculiar to them. Were these fishes then created in these separate water-systems as they now exist, or have they been transferred thither from some other water-bed? If not born there, how did they come there? Is there, or has there ever been, any possible connection between these water-systems? Are their characteristic species repeated elsewhere?" (Agassiz, Agassiz, 1868: 10). These reflexions make Agassiz the founder of the biogeography of Amazonian fishes (Fig. 1) and probably of South American fishes as a whole. Usually, the starting point of the field is considered to be Eigenmann (1909) (cf. Buckup, 1999; Ribeiro et al., 2011), but it is clear that Agassiz was the actual pioneer in the biogeography of fishes in the continent. Agassiz was also the first to notice that the Amazon is formed by distinct icthyofaunistic provinces: "... every day showing more clearly how distinctly the species are localized, and that this immense basin is divided into numerous zoological areas, each one of which has its own combination of fishes" (Agassiz, Agassiz, 1868: 241-242); "I will not fatigue you with my ichthyological researches; let me only add, that the fishes are not uniformly spread over this great basin. I have already acquired the certainty that we must distinguish several ichthyological faunae very clearly characterized" (Agassiz, Agassiz, 1868: letter to Milne Edwards: 221). Such insightful remarks were made almost half a century before Eigenmann (1909), the first author to explicitly divide the Amazon basin in different ichthyofaunistic regions.

Agassiz recognizes, again pioneeringly, that the Amazonian fish community is not homogeneously distributed in rivers: "I do not expect to find a single species of the Lower Amazons above Tabatinga" (Agassiz, Agassiz, 1868: 10). In 


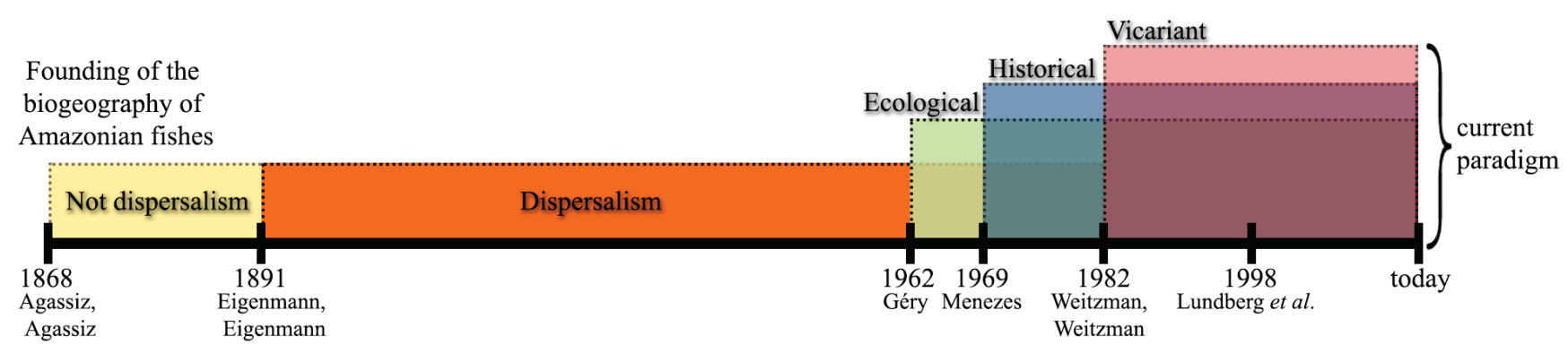

Fig. 1. Timeline of most important shifts in the understanding of the biogeography of Amazonian fishes.

a footnote in the same page, there is a commentary corroborating that hypothesis: "This anticipation was more than confirmed by the result of the journey. It is true that Mr. Agassiz did not go beyond the Peruvian frontier, and therefore could not verify his prophecy in that region. But he found the localization of species in the Amazons circumscribed within much narrower limits than he expected, the whole length of the great stream, as well as its tributaries, being broken up into numerous distinct faunae. There can be no doubt that what is true for nearly three thousand miles of its course is true also for the head-waters of the Amazons; indeed, other investigators have already described some species from its higher tributaries differing entirely from those collected upon this expedition" (Agassiz, Agassiz, 1868: 10-11). As noted by Eigenman, Eigenmann (1891), the pattern described by Agassiz is not specific to the Amazon basin, and is in fact a phenomenon common to all aquatic environments, both freshwater and marine: "This is nothing more than what is to be observed at a given locality of many rivers or along most coasts" (Eigenmann, Eigenmann, 1891: 12). So, Agassiz observations on the Amazon may have been the first to identify a worldwide pattern of distributional heterogeneity (Eigenman, Eigenmann, 1891).

Meanwhile, Agassiz also recognizes that there are species with narrowly endemic distributions and others, less numerous, with widespread geographical ranges: "My anticipations as to the distribution of fishes are confirmed; the river is inhabited by several very distinct ichthyological faunae, which have, as a common link, only a very small number of species to be met with everywhere" (Agassiz, Agassiz, 1868, letter to the Emperor: 203-304); and "Thus far I have met but a small number of species having a very extensive area of distribution. One of those is the Sudis gigas, found almost everywhere" (Agassiz, Agassiz, 1868, letter to Milne Edwards: 219). Eigenmann, Eigenmann (1891) have a critical view of the extreme endemism preconized by Agassiz, attributing it to misinterpretations of the morphological variation in the fishes he studied and that he ignored the fact that many of the referred species had already been described by other researchers from other regions. Indeed, the Eigenmanns were correct in their criticism because the narrow endemicity preconized by Agassiz was never confirmed in the Amazon and most of the species therein have broad distributions.
Agassiz is also the first to report on lateral migration of species, highlighting the relevance of drought-flood cycles in the distribution of the ichthyofauna: "The wanderings of the Amazonian fishes are rather a result of the alternate widening and contracting of their range by the rise and fall of the waters, than of a migratory habit; and may be compared to the movements of those oceanic fishes which, at certain seasons, seek the shoals near the shore, while they spend the rest of the year in deeper waters" (Agassiz, Agassiz, 1868: 345).

Equally pioneering was Agassiz's attempt to test the importance of migration as an explanation for the distribution of Amazonian fishes. He and assistants collected fishes in the same areas in different seasons. According to him, results show that the fish assembly did not change through time and thus were not the result of migration from one region to another: "As far as these comparisons have gone, they show that the distinct faunce of the above-named localities are not the result of migrations; for not only have different fishes been found in all these basins at the same time, but at different times the same fishes have been found to recur in the same basins, whenever the fishing was carried on, not merely in favored localities, but as far as possible over the whole area indiscriminately, in deep and shoal waters. Should it prove that at Pará, as well as at the intervening stations, after an interval of six months, the fishes are throughout the same as when we ascended the river, the evidence against the supposed extensive migrations of the Amazonian fishes will certainly be very strong" (Agassiz, Agassiz, 1868: 347); also "I have been frequently told here that the fishes were very nomadic, the same place being occupied at different seasons of the year by different species. My own investigations have led me to believe that these reports are founded on imperfect observations, and that the localization of species is more distinct and permanent in these waters than has been supposed" (Agassiz, Agassiz, 1868: 344). Although based on a limited time-scale, this line of thought distinguishes Agassiz from all other authors who advanced ideas on the subject (e.g. Eigenmann, Haseman, Darlington, Myers, Géry, Weitzman, Weitzman, etc.) and sets him apart as the only authors in the school of thought here called non-dispersalist.

It is not clear how Agassiz expected his Amazonian explorations to reveal data supporting his anti-evolutionist ideas. The ideas recorded in Agassiz, Agassiz (1868) are 
mostly pertinent observations and thoughts on the patterns found. It is also difficult to kow whether and to what degree his anti-evolutionist stance was influenced by his biogeographical observations in the Amazon. But the following passage from Agassiz, Agassiz (1868) indicates that they did not change much: "This is among the most remarkable instances of what I would call the arbitrary character of geographical distribution. Such facts cannot be explained by any theory of accidental dispersion, for the upper mountain rivulets, in which these great rivers take their rise, have no connection with each other; nor can any local circumstance explain the presence of some species in all the three basins, while others appear only in one, or perhaps in two, and are absent from the third, or the fact that certain species inhabiting the head-waters of these streams are never found in their lower course when the descent would seem so natural and so easy. In the absence of any positive explanation, we are left to assume that the distribution of animal life has primary laws as definite and precise as those which govern anything else in the system of the universe" (Agassiz, Agassiz, 1868: 12). This is one of the few passages where Agassiz, Agassiz (1868) express a more "abstract" view on fish distribution, and one which does not refer specifically to the Amazon, but to the fact that different fish species show different distributions. Although succeeding in recognizing several features of fish distribution, Agassiz failed in identifying their origins and maintained his belief in abstract forces controlling biological patterns.

The expedition led by Agassiz was rich in ideas, but its most lasting contribution to ichthyology was actually the thousands of fish specimens sampled, which was considered by Eigenmann, Eigenmann (1890) as the richest fish collection yet done in South America. The Thayer expedition was the first to have as main objective the collection of South American fishes (Böhlke et al., 1978) and, like Natterer's expedition, did not restrict its sampling efforts to large-sized species. Therefore, it had great importance in building taxonomic knowledge on small fishes, the most diverse in the Amazon. Such material permitted landmark contributions by C. Eigenmann and F. Steindachner in the second half of the $19^{\text {th }}$ century, forming the basis of Amazonian fish systematics (Myers, 1943). Those ichthyologists, incidentally, are still today first and second most prolific authors of Amazonian fish species. Agassiz also sponsored a 30-month sojourn by Steindachner at Harvard to study Thayer expedition material.

From 1848 to 1852, the Amazon was visited by Alfred R. Wallace (accompanied in part of the trip by Henry W. Bates), widely considered as the founder of evolutionary biogeography (George, 1964; Brown, Lomolino, 1998; Riddle, 2005; Morrone, 2009). Wallace was the first author to emphasize the importance of recognizing patterns of distribution of animal species in the Amazon: "On this accurate determination of an animal's range many interesting questions depend. Are very closely allied species ever separated by a wide interval of country? What physical features determine the boundar- ies of species and of genera? Do the isothermal lines ever accurately bound the range of species, or are they altogether independent of them? None of these questions can be satisfactorily answered till we have the range of numerous species accurately determined" (Wallace, 1852: 110). At the time, Wallace had yet to discover a mechanism for evolution, but nonetheless began to realize the importance of geographical barriers in the divergence of species. The influence of Amazonian rivers as barriers on terrestrial animals, most notably on birds, was clear to him during that trip (Wallace, 1853). In his travel journals and in publications, Wallace made few references to fishes, but in one of them he is the first to observe that water type influenced the fish species composition in different rivers: "Being a black-water river, most of its fishes are different from those found in the Amazon. In fact, in every small river, and in different parts of the same river, distinct kinds are found. The greater part of those which inhabit the Upper Rio Negro are not found near its mouth, where there are many other kinds equally unknown in the clearer, darker, and probably colder waters of its higher branches" (Wallace, 1889: 325). Wallace's hypothesis has been perpetuated or corroborated in several subsequent papers ( $c f$. Roberts, 1972; Kullander, 1986; Vari, 1988; Goulding et al., 1988; Araújo-Lima, Goulding, 1997; Saint-Paul et al., 2000).

The dispersalist school (late $19^{\text {th }}$ century and $20^{\text {th }}$ century). The first ichthyologist to tackle freshwater fish distribution from an evolutionary perspective was Günther (1880). That author was also the first to divide South America into two different ichthyological regions: Tropical American region (equivalent to Neotropical region) and The Patagonian sub-region. The Tropical American region is characterized by the presence of Dipnoi and Gymnotidae (= Gymnotiformes) plus a great diversity of Chromides (= Cichlidae) and Characinidae (= Characiformes). The region is classified in the equatorial zone of the world on the basis of the presence of Siluridae (= Siluriformes) and by the absence of Cypriniformes (thus in the Acyprinoid Division). Günther's simple classification is remarkably efficient and is still significant today, having survived over a century of additional knowledge on freshwater fish distribution and diversity and on the relationships of the South American continent with other land masses. In that same paper, Günther observes similarities (e.g. Chromides $=$ Cichlidae and Characinidae $=$ Characiformes) between the ichthyofauna of the tropical portion of South America and Africa, suggesting a close connection between those two continents in the past. His hypothesis postulates that the ancestral stock of both continents lived in an intervening land mass across the Atlantic, today submerged. Günther's (1880) idea was subsequently followed by numerous other authors ( $c f$. Eigenmann, Eigenmann, 1891; Eigenmann, 1909; Regan, 1922; Gosline, 1944). Although today's explanation is based on continental plate dynamics rather than land bridges, the hypothesis first proposed by Günther (1880) remains valid as a general explanation for 
the history of part of the biota in African and South America and is in fact one of the paradigms of freshwater fish biogeography ( $c f$. Roberts, 1972; Novacek, Marshall, 1976; Briggs, 1979, 2005; Gayet, 1982; Lundberg, 1993; Nakatani et al., 2011; Chen et al., 2013).

Also influential in the biogeographic worldview at this period is Hermann von Ihering, who staunchly defended the existence of past land bridges among earth's land masses, including between Africa and South America as proposed by Günther (1880). Ihering was a severe critic of Wallace's theory that depth lines were a proxy to establish the boundaries of ancient continents. The controversy between the hypothesis of land bridges and the alternative model of dispersal over present-day land masses forms an interesting parallel with the much later disputes between vicariance and dispersalism in the late $20^{\text {th }}$ century. An emblematic taxon in that controversy is the Galaxiidae, a freshwater fish family with a circum-Antartic distribution. Ihering had a strong opinion on the matter: "Mr. Wallace's explanation of the distribution of the Lacertidce through Polynesia as far as the Sandwich Islands by means of a migration across the ocean is just as bold a hypothesis as his attempt to explain the occurrence of identical fresh-water fishes in New Zealand and Patagonia by the transport of their fry on icebergs. To such theories may those adhere who wish to save Wallace's hypothesis of the stability of the continents and depths of the seas; but one cannot ask unprejudiced scientists to accept such incredible explanations. (Ihering, 1891: 443)". Ihering's ideas were compiled in their more or less final form in Ihering (1907), where he proposes that South America was formed by the union of two ancient continents called Archamazonia and Archiplata. The former comprised the central and northern portions of the continent, and the latter contained Southern Brazil, Uruguay, Argentina and Chile. Archiplata was connected in the south to an ancient Antartic continent called Archinotis. The paper also postulates the existence of Archhelenis, a continent that joined East Archamazonia to West Africa.

It is an interesting turn of history that the idea of earth crust stability was first challenged on biological rather than geological grounds. Both Günther's and Ihering's theories were based on facts about the distribution of living and fossil organisms that were impossible to explain on a stable surface of the planet. They realized that the geography of life made it virtually certain that continental configurations underwent major changes through time. As to the nature of those changes, there were several possibilities. Their model, land bridges and lost continents, was a solution that seemed least incompatible with the geological paradigm of the time. Of course, the real explanation was continental drift, first advanced in the prescient work of Wegener (1912) but discredited for over six decades thereafter. Still, Günther's and Ihering's conclusions about earth crust dynamism was convincing to biologists in general and their theories were followed, for example, by Eigenmann (1909) and Regan (1922).
The most lasting contribution by Ihering to the biogeography of neotropical fishes was the conclusion that a single territory may have different historical origins, dynamically and temporally, thus engendering hybrid biotas. The idea is explicit in two passages: "The intimate relations between the fresh water faunas of Africa and Brazil, and the colossal difference which exists between the fresh water faunas of Archamazonia and Archiplata, prove that both territories during the greater part of the Tertiary were separated quite as completely as the two Americas" (Ihering, 1900, p. 861); and "Thus Africa offers the same mixture of ancient indigenous elements and Neogene immigrants as Argentina and Southern Brazil, on account of the intrusion of archamazonic immigrants. Had this invasion occurred in the Eocene period, the Cyprinidae would have reached Brazil; supposing it to be Pliocene, these fishes would not have reached Madagascar. Probably Africa received its placental mammals at the same time that the invasion of Cyprinidae into Africa took place, one of the most remarkable events in zoogeography (Ihering, 1900: 863). Such wide-ranging grasp of planetary biogeography was a result of a vast knowledge about both living and fossil organisms and clearly influenced C. Eigenmann in his interpretations about the South American fish fauna (discussed below).

The transition between the $19^{\text {th }}$ and $20^{\text {th }}$ centuries is a period of dramatic increase in knowledge about neotropical fishes in general, and particularly about Amazonian fishes. In that period, dispersal interpretations were broadly adopted as a mechanism of biogeographical explanation, a trend which in zoology was largely determined by the works of C. Darwin and A. Wallace. The context of that time was already fully evolutionary and the dominance of dispersal as an explanation was strongly rooted in then prevailing paradigms about the stability of the earth's crust and biological centers of origin. Both concepts far predate the $19^{\text {th }}$ century and are inherited from much older pre-evolutionary cultural traditions (Browne, 1983; Papavero et al., 1995). In combination, such ideas culminated in the concept that organisms are responsible for their own distribution ( $c f$. Darwin, 1859; Wallace, 1876; Jordan, 1896; Simpson, 1953; Darlington, 1957).

One of the greatest ichthyologists at that period, David Starr Jordan, believed that a major part of South American drainages was connected, thus allowing direct passage of species between them: "Prof. John C. Branner calls my attention to a marshy upland which separates the valley of the La Plata from that of the Amazon, and which permits the free movement of fishes from the Paraguay River to the Tapajos. It is well known that through the Cassiquiare River the Rio Negro, another branch of the Amazon, is joined to the Orinoco River. It is thus evident that almost all the waters of eastern South America form a single basin, so far as the fishes are concerned"' (Jordan, 1896: 120).

It is in this context that the work of Eigenmann, Eigenmann (1891) was conceived. That paper was the first to formally search for biogeographical explanations in the Amazon from a dispersalist perspective. Their theoretical 
vision is explicit in many passages, for example: "The large number of genera found in the Amazons and La Plata which do not occur in the rivers of southeastern Brazil would lead one to conclude that the Amazonian genera reach the La Plata system directly, even if such connections as are known to exist were not known" (Eigenmann, Eigenmann, 1891: 20). The Eigenmanns thus became the main architects and propagators of the dispersalist school as applied to Amazonian fishes, a tradition which extended into the $20^{\text {th }}$ century (Fig. 1). It is also interesting to notice, however, that Eigenmann, Eigenmann also hint to the idea that patterns of faunal distribution may be the result of a different past geography, as seen above a result of the influence of $\mathrm{H}$. von Ihering. This idea foreshadows the paradigm later founded by Leon Croizat (Banarescu, 1990). The Eigenmanns also refine Günther's model and propose that the Tropical Region should be subdivided into Brazilian (= South American, excepting Patagonian region) and Mexican (= part of Central America) Regions and that the Brazilian sub region should be further divided into nine provinces: (1) Pacific, (2) Andean, (3) Magdalena, (4) Orinoco, (5) Guiana, (6) Amazonian, (7) San Franciscan, (8) Atlantic, (9) La Plata.

The subsequent work of Eigenmann (1909) is the most important publication on the biogeography of neotropical fishes in many decades. That paper slightly modifies the previous proposal of Eigenmann, Eigenmann (1891) and splits the American continent south of the tropic of Cancer into four different ichthyofaunas (Transition, Mexican, South American and Patagonian). The region "South American" is divisible into the Andean and Brazilian, the latter being formed by nine provinces: Central American, Pacific, Amazon, Trinidad, East Brazilian Plateau, San Franciscan, Coastal, La Plata, Guiana and Magdalena. Interestingly, some of those provinces are not delimited by hydrograhic basin, but rather by the terrain drained by them (e.g. Amazon, East Brazilian Plateau, Guiana). This demonstrated that Eigenmann (1909) also considered geology as an important factor in delimiting ichthyofaunistic regions inside the Amazon (Ribeiro et al., 2011), an idea that underlies the concept that geomorphological processes are more important than present-day basin divides to understand fish distribution.

Eigenmann (1909) applies the theory of Archiplata-Archhelenis of Ihering (1907) to part of South America. That theory proposed that in the Tertiary, Tropical America was formed by two land masses, Archiguiana and Archamazona, separated by a valley submerged by the sea. The Anden uplift formed the valleys of the Orinoco, Amazonas and rio Paraná, which then begin to be occupied by freshwater. The Amazon, in particular, was colonized by fishes from older regions and became the center of an adaptive radiation which dispersed to other regions: "With the further elevation of the Cordilleras into a continuous barrier and the formation of the Orinoco, Amazon and La Plata valleys through elevation and the debris brought from the land masses, and the development of the enormous fresh-water system occupying these valleys, this system, particularly the Amazon, became colonized from the older land areas and became the center of unparalleled adaptive radiation and a new center for distribution, which it has remained to the present time" (Eigenmann, 1909: 371).

Eigenmann (1909) is the first to distinguish, ichthyologically and biogeographically, the sedimentary basin of the Amazon (Lowlands) from the Brazilian and Guyanan Shields (Highlands), clearly delimiting differences in their geomorphological ages and faunistic colonization: "The lowlands through which these main rivers flow are the youngest part of South America. The parts that first arose out of the sea and became populated with fresh-water fishes were probably two land areas. The one embraces the highlands of Guiana and Northern Brazil, the other the highlands of Brazil east of the Araguay and south of the falls of the Tapajos" (Eigenmann, 1909: 318). Such Highland/Lowland divide is one of the most strongly corroborated patterns in Amazonian fish distribution in modern works ( $c f$. Jégu, 1992a, 1992b; Ribeiro et al., 2011; Dagosta, de Pinna, 2017).

In the same paper, Eigenmann also proposes that the fish fauna of the Amazon has a hybrid origin, with lineages from both the Northeast and Southeast of the continent: "These interior rivers, chiefly the Amazons, colonized from the northeast and southeast became themselves the seat of unparalleled adaptive radiation and centers of distribution, as we shall see" (Eigenmann, 1909: 318). Thus, Eigenmann (1909) is clearly the first author to propose a reticulated history to the Amazonian fishes, a hypothesis which has been repeatedly corroborated in recent works and is one of the prevailing paradigms in the biogeography of the basin (cf. Hubert, Renno, 2006; Ribeiro, 2006; Lima, Ribeiro, 2011; Dagosta et al., 2014; Dagosta, de Pinna, 2017).

Haseman (1912) criticizes most of the proposals by Eigenmann (1909), arguing that the large quantity of taxa in a given region does not imply that it is the center of origin and dispersal of that group. Haseman, however, fails in his attempt to refute Eigenmann's hypothesis that similarities between the Paraguay and Amazonas were explained by dispersal. To Haseman (1912) those similar biotas resulted from adaptive parallelism caused by similar environments: "Why have the Paraguayan species remained identical with the Amazonian? Why did not more of the Cichlidae of Rio Guapore enter the Paraguay? My answer to these questions is that similar environments have produced some similar changes in the same germplasm" (Haseman, 1912: 71).

Carl Eigenmann publishes a series of papers (Eigenmann 1920, 1921a, 1921b, 1923) discussing the composition of the ichthyofauna in Trans-Andean drainages, emphasizing the high level of endemism and the conspicuous absence of several lineages in that region. He discusses the origin of the Trans-Andean biota, proposing that it is composed mainly of Amazonian lineages. Although not explicitly stated, Eigenmann's works also reveal his idea about the importance of the Andean range for the diversification of Trans-Andean fishes and the hypothesis that the diversification of Amazonian lineages predates the Andean uplift. All such 
hypotheses have been corroborated in subsequent works ( $c f$. Lundberg, Mago-Leccia, 1986; Lundberg, Aguilera, 2003; Albert et al., 2006; Lundberg et al., 2010; Rodríguez-Olarte et al., 2011) and highlight Carl Eigenmann's extraordinary role in the understanding of the biogeography of neotropical fishes, particularly in the Amazon.

A paper remarkably ahead of its time is Pearson (1937), which proposes that the ichthyofaunistic relationships between the Paraguay and Amazon basins were the result of dispersal, with lineages from the latter having colonized the former: "The close resemblance of the fishes of the Paraguay to the enormous and diversified fauna of the Amazon indicates their origin from the Amazonian forms. Furthermore, the nature of the divide between the two basins indicates that the fishes of the Amazon basin have had access to the Paraguay basin (Pearson, 1937: 104). The author offers a modern view of the dynamics of biogeographic barriers and clearly realizes that present-day barriers were not necessarily effective through geological time: "The fishes entered South America sometime during the Tertiary and crossed the low Amazon valley and a highland divide to enter the Paraguay. Other tributaries of the Amazon in addition to the Rio Guaporé seem to have been migratory paths. The falls in the streams flowing from the highlands of Matto Grosso seem to be barriers to free migration at the present time; but the nature of the fishes of the two slopes indicate that the barrier is of recent origin" (Pearson, 1937: 107). Pearson's work remains today the main reference in the shared ichthyofauna between the Madeira and the Paraguay. Such sharing has been corroborated and reinforced in many recent papers ( $c f$. Kullander, 1986; Shibatta, Pavanelli, 2005; Hubert, Renno, 2006; Carvalho, Albert, 2011; Ribeiro et al., 2013; Ota et al., 2014; Dagosta, de Pinna, 2017).

Darlington (1957) describes a general pattern of South American freshwater fish distribution in which there would be a decrease in species richness away from the Amazon basin, most strongly southwards. Darlington (1957) agrees with Eigenmann (1909) that the Amazon was the center of diversity in South America, however differs in considering it as the only center, while Eigenmann proposed various centers "There seems to be only one main South American fauna of true fresh-water fishes, which radiates from the Amazon, and parts which are extended or subtracted or localized or specialized in different places about as would be expected in the diverse habitats of a continent like South America" (Darlington, 1957: 72). Once again, Eigenmann's grasp of the situation is remarkable in foreseeing a hybrid origin for Amazonian fishes, something that escaped Darlington entirely.

As knowledge on South American ichthyology and hydrography improves, it becomes increasingly clear that the traditional dispersalist edifice build by Eigenmann and associated land bridges were not sufficient to explain the patterns of distributions of South American freshwater fishes. The evident complexity of the situation marked the limits of a tradition, and required a new model which integrated multi-layered explanations.
The influence of ecology (middle of $20^{\text {th }}$ century to the present). The publication of Myers (1938) is one of the first signs of the fusion between the then prevailing ideas of dispersal with the Harvard school, characterized by a strong ecological penchant. To Myers, freshwater fish lineages must be distinguished according to their tolerance to salinity, a well-known limiting factor to fish distribution. Myers (1947) follows the dispersalist tradition established by Eigenmann, underscoring that the Amazon is the largest body of water in a series of gigantic connections in South America, especially with the Orinoco. Myers (1947) states that it is possible that a fish to "swim" a large portion of South America with no barriers, a conjecture which, for him, explains the presence of certain species in almost all basins east of the Andes.

Some decades later, papers by J. Géry begin to aggregate a strongly ecological tint in the biogeography of neotropical fishes (Fig. 1). Although still firmly grounded in the dispersalist tradition, Gery's papers set the tone for the upcoming prevailing view on Amazonian fish biogeography and can be considered as the start of that tradition.

Géry (1962) recognizes so-called circumferential pattern (lateral migration between basins) for some species of fish. The author uses as example the distribution of species of the genus Hemibrycon, which occur around Amazonian lowlands, but never in lowlands themselves. To Géry, this pattern is the result of ecological constraints inherent to the taxon, restricted to fast water mountain streams with high oxygen levels. On the other hand, the lateral movement among mountain drainages still resorts to dispersalist theory: "The Characoids (at least) have shown that they can pass readily from one basin to another in a very short time, geologically speaking. In fact, all the great (or reduced) basins are more or less connected by canals or swamps, either permanently or during the rainy season. The less 'conservative' of the Characids show a tendency to invade laterally their adjacent basins (by means of these temporary or permanent connections), whereas they are often stopped along their own river by some ecological barrier..." (Géry, 1962: $67)$. The author refers to the old idea of dispersal routes crossing limits of upper reaches of basins, thus allowing range expansions. On the other hand, Géry (1962) newly introduces a more modern interpretation applicable to widely distributed species in general, and one which explains their range by opportunistic colonization of suitable habitats. Although seemingly a subtle difference, such idea differs strongly from that of other dispersalists, who considered that species migrated forcedly, always in response to geological events, marine invasions or competition with other taxa. The same view is later defended by Weitzman, Weitzman (1982), but without mention to Géry.

Another pioneering hypothesis by Géry (1962) proposes that the rio Amazonas itself can act as barrier to some species of fish: “... the lower part of the Amazon itself constituted the best barrier to prevent it from propagating to the south" (Géry, 1962: 68). It is clear that Géry (1962) starts the 
realization that the scenario proposed by Eigenmann (1909) was no longer sufficient to explain fish distribution. The idea of an Amazon basin freely connected within itself and with neighboring basins is attacked for the first time.

In another paper on the fishes of the rio Araguaia, Géry (1964) realizes that the fish fauna of that drainage is composed of three components: endemic species; species shared with the headwaters of the Tocantins and Xingu; and species with closest relatives in the Upper Orinoco and Guyana Shield (e.g. Moenkhausia grandisquamis (Müller, Troschel, 1845)). Although Eigenmann (1909) had already suggested a hybrid Amazonian ichthyofauna, Géry (1964) was the first to propose the same for a subdrainage (Araguaia) inside the Amazon basin.

In a subsequent paper, Géry (1984) discusses several factors which have contributed to the diversification of fishes in the Amazon. Among those is mention of a lake, which implicitly suggests that the author considered sympatric speciation as a factor in the generation of Amazonian diversity: "The great tertiary lake preceding the Amazon itself may have acted as the present Great Lakes (in Africa, Nicaragua, etc.) do in favoring the so-called "explosive" speciation" (Géry, 1984). This view is similar to that later defended in Frailey et al. (1988). Another relevant insight in Géry (1984) is that the ichthyofaunistic similarities between the Brazilian and Guyanan Shields is due to ancient connections predating the formation of the rio Amazonas.

Of all pioneering proposals by Géry, the most important one is the idea about the fragility and evanescence of hydrographic basin limits and their potential for faunistic exchange. This is clearly expressed in Géry (1969: 833): “It is thus naive to believe that fresh-water fishes 'are almost inescapably confined to their own drainage system". Géry is therefore the first author after Eigenmann to recognize the great dynamism of South American drainages and its impact on the distribution of fishes.

Roberts (1972) provides a summary of various geological, behavioral and ecological processes that were directly and indirectly responsible for the diversification of the Amazonian fish fauna. Among those is an original finding that species with conspicuous colors are far more abundant in clear- or blackwater rivers than in whitewater ones, and that water color influenced mechanisms of intraspecific recognition: "At least for the majority of characoids, however (which provide most of the best examples of brilliantly colored fishes both in the Amazon and in the Congo), there is no indication whatever that they are inedible or dangerous in any way to predators. It would seem, although there are no data available to support this, that the brightly colored characins are just as subject to predation as drably colored ones, if not even more. In this respect the colors advertizing their presence are probably a disadvantage. Many of the small, brightly colored Amazonian characins form schools. This is true of the most brilliant characins of all, the neon tetras and cardinal tetras. Most of these brightly colored characins live in black water or clear water igarapés, a habitat that can be highly temporary. Thus, populations frequently are split up or dispersed, and species recognition and schooling habits are probably important means of reconstituting populations" (Roberts, 1972: 132). Roberts' (1972) hypothesis has been repeatedly corroborated and colorful characin species are indeed far more numerous in clear- or blackwater rivers and streams ( $c f$. Bertaco, Carvalho, 2005a, 2005b; Carvalho, Bertaco, 2006; Lima, Birindelli, 2006; Lima et al., 2007; Bertaco, Malabarba, 2007; Sousa et al., 2010; Bertaco et al., 2011; Ingenito et al., 2013; Mattox et al., 2013; Netto-Ferreira et al., 2013; Marinho et al., 2014; Pastana, Dagosta, 2014; Dagosta et al., 2015; Ohara, Lima, 2015).

In a paper on the cichlid fishes of Peru, Kullander (1986) recognizes some biogeographical patterns in the Western Amazon, such as the Highlands and Lowlands, and suggests the Western Amazon as an area of endemism. The author offers important considerations about Amazonian biogeography and the role of ecological constraints on the distribution of species, confirming Géry's (1962) hypothesis. Kullander (1986) also suggests the possible ichthyofaunistic hybridism of the rio Solimões. Kullander implicitly proposes speciation under character displacement as a possible mechanism in the generation of the diversity of Amazonian fishes: "Overlapping distribution and lack of phylogenetic data precludes detailed analysis of Bujurquina distribution. Sympatry indicates dispersal, but it may be significant that syntopic occurrence of Bujurquina species is a rare phenomenon, recorded only for $\mathrm{B}$. labiosa and $\mathrm{B}$. robusta. These two species differ greatly in mouth structures, suggesting different feeding niches. Competitive interaction might be taken to be responsible for much of the habitat separation in Bujurquina species, and the group may be an example of Morphological modifications and biotope selectivity may have been inforced rather by eventual sympatry than by isolation" (Kullander, 1986: 35).

Jégu, Keith (1999) describe a pattern where there is a decrease in species diversity from Central Amazon towards its mouth and the rivers of French Guyana. The authors support their observations mainly on species of Serrasalmidae and explain the pattern by ecological and behavioral processes.

Menezes (1972), on the basis of Brazilian drainages only, empirically tests Eigenmann's (1909) theory on the role of the Amazon as a center of origin and dispersal for the neotropical fish fauna, corroborating it. Although the coefficients used by the author are simple, they constitute the first instance of explicit testing of a biogeographic hypothesis in the Amazon. A similar approach was employed by Géry (1984). Both works were later criticized by Vari (1988) for not offering evidence for the temporal sequence of events which generated the patterns described.

Menezes $(1969,1976)$ explain the ichthyofaunistic differences between Amazonian Highlands and Lowlands from a dispersalist angle in which species are forced to move (Fig. 2a). The author suggests that the Acestrorhynchini and $\mathrm{Cy}$ nopotaminae radiated in the Amazon and that more derived younger forms "pushed" less derived older species towards 
a)

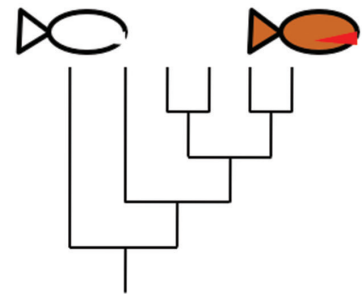

b)

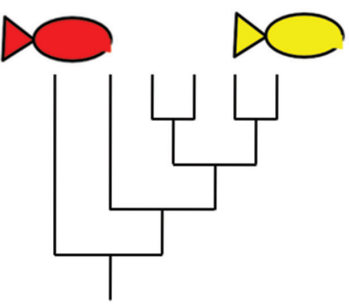

t0

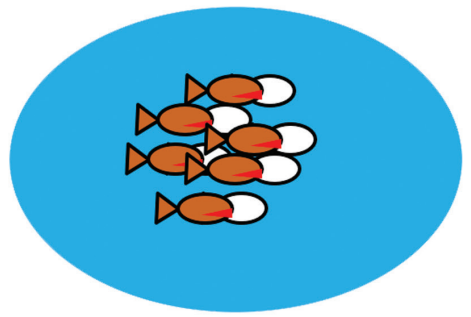

t0

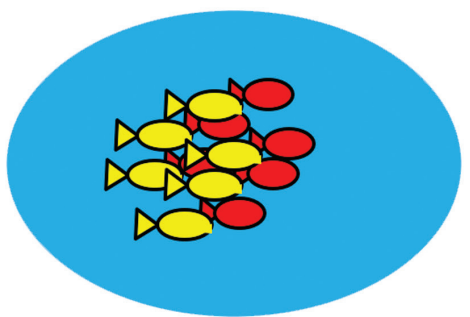

$t 1$

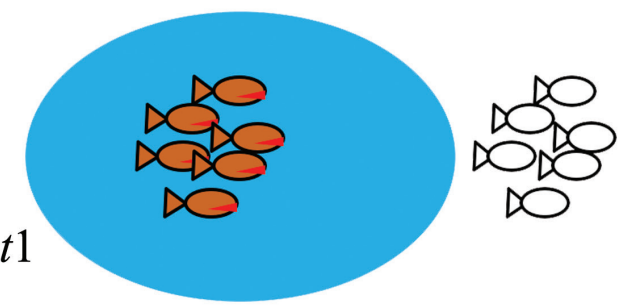

$t 1$

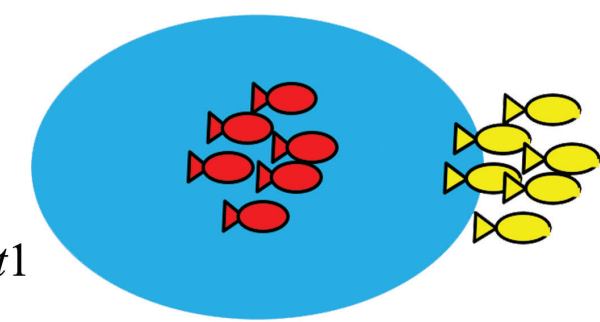

Fig. 2. a) Traditional dispersalist hypothesis (e.g. Menezes, 1969, 1976) in which basal species are forced to move to the periphery. Distribution of derived species indicated the location of the center of origin of its lineage. b) Willi Hennig's hypothesis in which the primitive species retained their geographic position while younger ones spread towards the periphery. Distribution of primitive species indicated the location of the center of origin of its lineage.

the periphery by competition: "The Amazon Basin remains the place where adaptive innovations (and consequently radiations) occur. The forms generated there tend to push the older species towards the periphery where they remain, at least for a time, in marginal ecologies" (Menezes, 1976:19). Those are the first papers to discuss fish distribution in view of their evolutionary relationships and can be considered as transitional between the dispersalist and vicariant phases of the biogeography of Amazonian fishes (Fig. 1). Although not explicitly phylogenetic because of their temporal frame, Menezes' works foreshadow the upcoming paradigm that biogeographic hypotheses must be based on knowledge about evolutionary relationships.

Transition to vicariant school (late $20^{\text {th }}$ century). For centuries, dispersalism prevailed as an explanation for the geographical distribution of organisms on earth (Crisci et al., 2003), an intellectual tradition that can be traced as far back as Old-Testament myths in the Pentateuch (Browne, 1983; Papavero et al., 1995). In the evolutionary era, such tradition was adapted but not discarded. In the evolutionary dispersalist tradition it was generally accepted that more derived younger species forced the displacement of primitive older ones towards the periphery of their range. Thus, the distribution of derived species indicated the location of the center of origin of its lineage. The work of Willi Hennig (Hennig, 1950, 1966), although revolutionary in proposing a new phylogenetic theory, largely followed the dispersalist paradigm in biogeography. Contrary to the mainstream (but not originally so), for Hennig the relative position of derived and primitive species were inverted: the latter retained their geographic position while younger ones spread towards the periphery (Fig. 2b). Therefore, the most primitive members of a lineage indicated its center of origin. The same view was adopted in Brundin (1966), one of the landmark works on biogeography of the $20^{\text {th }}$ century. The multiplicity of criteria to locate the center of origin of a group had been previously compiled by Cain (1944), who pointed out that many of them were contradictory and permitted widely divergent hypotheses about the geographic origins of a group. Although Cain had all elements to challenge the dispersalist paradigm, he curiously did not do so and failed to come up with a theoretical alternative (Nelson, Platnick, 1981).

A real shift comes with the work of L. Croizat (Croizat, $1958,1964)$ which frontally attacks the idea of center of origin, and therefore the dispersalist paradigm, in proposing to replace it with panbiogeography and its motto that "life and earth evolve together". Towards the late 1970's and early 1980 's, Croizat's panbiogeography was combined with Hennig's phylogenetic theory to form the vicariant school of biogeography (e.g. Croizat et al., 1974; Bãnãrescu, 1990). That period also saw the rise of modern plate tectonics, which provided a dynamic geological setting particularly suitable as a background for the vicariant paradigm. Although Hennig was clearly a dispersalist thinker and failed to see the full biogeographic potential of his phylogenetic theory, his work was a key element in the collapse of the dispersalist edifice.

The development and application of vicariant biogeography (Rosen, 1976, 1978; Nelson, Rosen, 1979; Nelson, Platnick, 1981; Humphries, Parenti, 1985, 1999; Ebach, Tangney, 2007; Williams, Ebach, 2008; Parenti, Ebach, 2009), allowed the development of quantitative methods for the study of coevolution between organisms and their areas, on the basis of explicitly phylogenetic hypotheses. Dispersalist 
models were quickly replaced by vicariant biogeography. The latter was perceived as a more efficient way to study historical biogeography, since it identified general patterns of distribution and their general explanations (Rosen, 1976). Such paradigm shift brought closer interaction between biology and geology which in Rosen's vision (Rosen, 1978) were "reciprocal illuminators". The new vicariant perspective also begins to erode the relevance of ecology as a source of biogeographic explanation, because it was seen as providing only local specific criteria of species distributions, rather than a source of general biogeographic hypotheses.

The first explicitly phylogenetic work to deal with Amazonian fishes was Vari (1977) and the first paper to discuss Amazonian fish biogeography from a vicariant perspective was Weitzman, Weitzman (1982) (Fig. 1). On the basis of the distribution and phylogenetic relationships of the genera Carnegiella (Gasteropelecidae) and Nannostomus (Lebiasinidae), Weitzman, Weitzman try to correlate the patterns found with Refuge Theory (Haffer, 1969, 1982; Prance, 1982). The authors conclude that if there is any relation between refuges and the diversification of the studied genera, it happens at the population level or, at most, between closely related species. Weitzman, Weitzman also warns about the need of greater evolutionary, taxonomic and distributional knowledge before more accurate biogeographic hypotheses can be formulated. In what concerns the Amazon, the main conclusion of their paper is that the diversification of its fish fauna is pre-Pleistocenic, dismissing Haffer's Refuge Theory as an explanation for that diversity. Such views contradict a long chain of authors who considered the diversification of amazonian fishes as a recent phenomenon, largely associated with the Andean uplift ( $c f$. Eigenmann, 1909; Géry, 1969, 1984; Roberts, 1972, 1975; Brooks et al., 1981; Frailey et al., 1988). Weitzman, Weitzman's (1982) hypothesis has been largely corroborated in subsequent work ( $c f$. Lundberg et al., 1986, 1988, 2010; Vari, 1988; Lundberg, Chernoff, 1992; Bush, 1994; Lundberg, 1997, 2005).

Starting in the early 1980's, Richard Vari begins a series of papers on the taxonomy and phylogenetic relationships of the family Curimatidae ( $c f$. Vari 1982; 1984; 1988; 1989a; 1989b; 1989c; 1989d; 1991; 1992a; 1992b). Having built detailed information on the distribution and phylogenetic relationships among species, Vari includes biogeographic discussions in many of those works. As a side product, maps of distributions included in several of those taxonomic revisions served as templates for general distribution patterns today known for Amazonian fishes (e.g., Vari, 1988).

Vari (1988) is the first author to propose a hybrid origin for the Amazon on the basis of phylogenetic relationships of its taxa, showing that different taxa indicate different historical connections. The author also points out to importance of ecological preferences (water type, current speed etc.) and behaviors (migration, vagility) in the distribution of species. The most relevant contribution of that work is the defense of biogeography as a predictive discipline, as long as it is associated with phylogenetic hypotheses. Vari demonstrates that the diversification of the Curimatidae happened before the Andean uplift, confirming the hypothesis by Weitzman, Weitzman (1982) and at the same time contradicting various previous authors (e.g., Eigenmann, 1909; Géry, 1969, 1984; Roberts, 1972). Vari (1988) thus underscores the relevance of understanding phylogenetic relationships in order to understand the biogeography of neotropical fishes, a view reiterated in Vari, Weitzman (1990).

Other relevant contributions of that period include Jégu (1992a, 1992b), which propose that the diversification of rheophilic especies in the Eastern Amazon during the Quaternary was determined by sea level fluctuations and associated droughts. On the basis of a pattern of the exclusive sharing of some groups of Characiformes, those papers also propose a biogeographical pattern for the Eastern Amazon involving prior connections between the Brazilian and Guyana Shields, similar to the one previously proposed by Géry (1964). Differently from the latter author however, Jégu (1992b) for the first time proposes a vertical correspondence among shield rivers "Les évènements ayant été à l'origine de ces phénomènes semblent avoir opéré indépendamment dans le bas Amazone, au niveau du Tocantins-Xingu et du Jari d'une part, et dans le moyen Amazone, au niveau du Tapajos et du Trombetas d'autre part» (Jégu, 1992b: 284). Jégu (1992b) describes a pattern of lateral migration between shield basins, similar to that by Géry $(1962,1969)$. Again, however, the author differs in being explicit about a vicariant explanation for the pattern: «La dispersion est/ouest, tant entre les affluents de la marge nord de l'Amazone qu'entre ceux de la marge sud, ne peut donc s'expliquer que par le morcellement d'une aire de distribution commune» (Jégu, 1992b: 285).

Starting in the middle of the 1980's, a growing number of taxonomic revisions and phylogenetic hypotheses is published for different groups of Amazonian fishes (e.g. Mago-Leccia et al., 1985; Weitzman, Fink, 1985; Kullander, 1986; Lundberg et al., 1986; Stewart, 1985, 1986; Ferraris, 1988). This marks the beginning of modern understanding about the taxonomy, distribution and phylogenetic relationships of Amazonian fishes. At the same time, publications start on various trans-Andean fossils that can be identified as belonging to typically Amazonian lineages, thus for the first time allowing a firm temporal framework for the biogeography of Amazonian fishes (cf. Lundberg et al., 1986, 1988; Lundberg, Chernoff, 1992; Lundberg, 1997, 2005; Sabaj Pérez et al., 2007). Furthermore, if such fossils were not known, our understanding of the biogeographical history of the region would be severely incomplete or incorrect, since they belongs to typically lowland Amazonian lineages which inhabit regions currently lacking any Amazonian connection, such as Magdalena and Caribbean coastal rivers from the northern coast of Venezuela: Arapaima, Brachyplatystoma, Colossoma, Doras, Hydrolycus, Phractocephalus and others (Lundberg et al., 1986, 1988, 2010; Lundberg, 1997, 2005; Sabaj Pérez et al., 2007; G. Ballen, personal communication). These tertiary fossils demonstrate that such regions were in the past also part of the lowland Amazonian basin. 
The reciprocal illuminators (late $20^{\text {th }}$ century to today). A new phase of biogeographical studies on neotropical fishes begins with Lundberg et al. (1998) (Fig. 1). That paper compiles and revises the main geological features of South America and their implications for the history of the ichthyofauna. It allows the interpretation of biogeographical patterns in light of geomorphological knowledge previously scattered in myriad isolated specialized publications. Lundberg et al. (1998) triggers a flood of papers following similar lines (e.g. Albert et al., 2006; Hubert, Renno, 2006; Lovejoy et al., 2006, 2010; Hubert et al., 2007; Sabaj et al., 2007; Albert, Carvalho, 2011; Bloom, Lovejoy, 2011; Carvalho, Albert, 2011; Salcedo et al., 2011; Schaefer, 2011; Winemiller, Willis, 2011; Mariguela et al., 2013; Ribeiro et al., 2013; Slobodian, Bockmann, 2013; Ivanyisky, Albert, 2014; Roxo et al., 2014; Silva et al., 2014; Ribeiro, Menezes, 2015 and many others). Most of those contributions focus on specific biogeographical patterns and some introduce analytical approaches in their analyses (e.g. Hubert, Renno, 2006; Albert, Carvalho, 2011; Schaefer, 2011; Mariguela et al., 2013; Roxo et al., 2014). Three publications deserve especial mention because they offer original synthetic views which consolidate the current trend in the biogeography of Amazonian fishes: Lundberg et al. (2010), Ribeiro (2006) and Lima, Ribeiro (2011). The first one presents a new interpretation of the reasons which made the Amazon basin megadiverse. Following Ashton (1969), the authors concur that there is no evidence for accelerated speciation rates in the basin, but that its sheer size helped to protect species from large-scale extinction events. Accordingly, the large diversity in the Amazon would be a consequence of the summation of multiple lineages through time: “... there are a number of prevailing conditions in the Amazon that could buffer species from basin-wide extinction. Area matters, and the Amazon is vast... A fauna experiencing low extinction rates and 'normal' speciation rates would become rich over time" (Lundberg et al., 2010).

Along a different perspective, Ribeiro (2006) and Lima, Ribeiro (2011) offered a view of the hydrographic basins in South America and their fish fauna which is far more complex than previously thought. They recognized that hydrographic basins should not be seen as areas of endemism, but rather as hybrid historical units which were fragmented and/or exchanged biotic fractions from adjacent basins caused by a series of events at different times. Although this idea was already implicit in Eigenmann (1909) and Géry (1964), the proposals of Ribeiro (2006) and Lima, Ribeiro (2011) have great merit in basing their discussions on geological evidence, demonstrating the fragility of hydrographic limits and challenging their use as a basis for delimiting biogeographical areas.

Recently, Dagosta, de Pinna (2017) demonstrated empirically that large Amazonian river drainages and the rio Amazonas basin itself were non-monophyletic and constitute hybrid sets of heterogeneous biotic partitions. Those hydrographic bodies are not cohesive historical units, but rather massively reticulate physical entities, composite in their geology, biology, and chronology.
Past and future. Endler (1982) states that biogeography: “... has become divided into schools which largely ignore one another". The historical narrative here presented shows that this does not in fact happens with the biogeography of Amazonian fishes. Although it is clear that the two main schools of biogeographical thought (dispersalist and vicariant) had direct implications on the interpretation of Amazonian fish biogeography, the process was gradual and many hypotheses have combined elements from each of the two traditions. Besides, several of the hypotheses which are part of today's paradigm on the biogeography of Amazonian fishes are based on principles and ideas dating back to the period between the latter half of the $18^{\text {th }}$ century and the first half of the $19^{\text {th }}$ century. That period covers several different biogeographical traditions. As pillars of specific theoretical schools are replaced, specific elements are transmitted into the next paradigm during transition phases, attenuating the paradigm shift and preserving those elements which have demonstrated to have explanatory power.

Although the advent of evolutionary theory has revolutionized biological sciences in general, it has not contributed significantly to a transformation of the knowledge on the biogeography of Amazonian fishes. Its founder, Agassiz, was an anti-Darwinian, but this fact did not blur his vision on the distribution of Amazonian fishes. A reverse situation happens with Hennig $(1950,1966)$, who revolutionized phylogenetic reconstruction but whose impact on Amazonian fish biogeography was belated. A major revolution in the field happens only in the 1980's, with the publications of Stanley Weitzman and Richard Vari. Those authors for the first time associated the temporal context of phylogenetic hypotheses with the biogeographical patterns then emerging as a consequence of the pronounced increase in knowledge on the Amazonian ichthyofauna. From its founding in 1868, the biogeography of Amazonian fishes only underwent major theoretical shifts during the last three decades, a development which is still underway.

Vari, Weitzman (1990) highlighted problems which have delayed proposition of general hypotheses on the phylogenetic biogeography of South American fishes. Those problems were the poor state of knowledge of the species-level systematics of most taxa; inadequate distributional information for most species and the sparse or non-existent data on the phylogenetic history of most supraspecific taxa. Almost three decades later, it is clear that those caveats are being corrected at a fast pace. The biogeography of South American fishes, especially Amazonian ones, should experiment a new age of progress. Recent advances in the knowledge about geographical distribution and a large number of available phylogenetic hypotheses will allow a growing number of large-scale biogeographic analyses, including those based on event models and Bayesian inference. The challenge of those new approaches will depend on their ability to segregate multiple overlapping temporal layers of river basin changes, and to develop analytical tools that can deal with temporal mixing. 


\section{Acknowledgments}

We thank Flávio Lima, Roberto Reis, Sílvio Nihei and Náercio Menezes for valuable comments on various versions of this manuscript and Gustavo Ballen for information and conversations on fossil South American faunas. We are also deeply indebted to the generosity and friendship of Heraldo Britski, an inexhaustible source of knowledge about neotropical fishes. Authors were funded by FAPESP (FCPD, 2011/23419-1; 2011/50282-7; 2016/07246-3), CNPq (MP) and CAPES (MP). This work was part of the Doctoral Dissertation by the first author, defended in the Graduate Program on Systematics, Animal Taxonomy and Biodiversity of the Museum of Zoology, Universidade de São Paulo. Part of the manuscript was prepared during a sabbatical stay of the second author in the Muséum national d'Histoire naturelle and Université Pierre and Marie Curie (Institut de Systematique, Evolution et Biodiversité), Paris, and the support and hospitality of René Zaragueta-Bagils and Guillaume Lecointre is gratefully acknowledged.

\section{References}

Agassiz L, Agassiz ECC. A journey in Brazil. Boston: Ticknor and Fields; 1868.

Akerman JR. The Imperial map: cartography and the mastery of empire. Chicago: The University of Chicago Press; 2009. (The Kenneth Nebenzahl Jr. Lectures in the History of Cartography).

Albert JS, Carvalho TP. Neogene assembly of modern faunas. In: Albert JS, Reis RE, editors. Historical biogeography of Neotropical freshwater fishes. Berkeley, Los Angeles, London: University of California Press; 2011. p.119-136.

Albert JS, Lovejoy NR, Crampton WGR. Miocene tectonism and the separation of cis- and trans-Andean river basins: evidence from Neotropical fishes. J South Am Earth Sci. 2006; 21(12):14-27.

Araujo-Lima C, Goulding M. So fruitful a fish: ecology, conservation and aquaculture of the Amazon's Tambaqui. New York: Columbia University Press; 1997. (Biology and Resource Management Series).

Ashton PS. Speciation among tropical forest trees: some deductions in the light of recent evidence. Biol J Linn Soc Lond. 1969; 1(1-2):155-96.

Bãnãrescu P. Zoogeography of freshwaters. Wiesbaden: AULAVerlag; 1990. vol. 1, General distribution and dispersal of freshwater animals.

Bertaco VA, Carvalho TP. New characid fish, Hemigrammus skolioplatus (Characiformes: Characidae) from upper rio Tapajós drainage, Central Brazil. Comun Mus Ciênc PUCRS. 2005a; 18(2):141-50.

Bertaco VA, Carvalho TP. Anew characid fish, Hyphessobrycon hexastichos (Characiformes: Characidae) from Chapada dos Parecis, Mato Grosso, Brazil. Neotrop Ichthyol. 2005b; 3(3):439-43.

Bertaco VA, Malabarba LR. A new species of Hasemania from the upper rio Tapajós drainage, Brazil (Teleostei: Characiformes: Characidae). Copeia. 2007; 2007(2):350-54.

Bertaco VA, Jerep FC, Carvalho FR. A new characid fish, Moenkhausia aurantia (Ostariophysi: Characiformes: Characidae), from the upper rio Tocantins basin in Central Brazil. Zootaxa. 2011; 2934:29-38
Bloom DD, Lovejoy NR. The biogeography of marine incursions in South America. In: Albert JS, Reis RE, editors. Historical biogeography of Neotropical freshwater fishes. Berkeley, Los Angeles, London: University of California Press; 2011. p.137144.

Böhlke JE, Weitzman SH, Menezes NA. Estado atual da sistemática dos peixes de água doce da América do Sul. Acta Amazon. 1978; 8(4):657-77.

Briggs JC. Ostariophysan zoogeography: an alternative hypothesis. Copeia. 1979; 1979(1):111-18.

Briggs JC. The biogeography of otophysan fishes (Ostariophysi: Otophysi): a new appraisal. J Biogeogr. 2005; 32(2):287-94.

Brooks DR, Thorson TB, Mayes MA. Fresh-water stingrays (Potamotrygonidae) and their helminth parasites: Testing hypotheses of evolution and coevolution. In: Funk VA, Brooks DR, editors. Advances in Cladistics, Proceedings of the First Meeting of the Willi Hennig Society. New York: New York Botanical Garden; 1981. p.147-175.

Brown JH, Lomolino MV. Biogeography. 2nd. Massachusetts: Sinauer Associates, Inc. Publishers; 1998.

Browne J. The secular ark: studies in the history of biogeography. New Haven: Yale University Press; 1983.

Brundin L. Transantarctic relationships and their significance, as evidenced by chironomid midges. With a monograph of the subfamilies Podonominae and Aphro-teniinae and the Austral Heptagyiae. Stockholm: Almqvist \& Wiksell; 1966. (Kungl. Svenska vetenskapsakademiens handlingar; No. 1).

Bucukp PA. Sistemática e biogeografia de peixes de riachos. In: Caramaschi EP, Mazzoni R, Bizerril CRSF, Peres-Neto PR, editores. Ecologia de Peixes de Riachos: estado atual e perspectivas. Rio de Janeiro: Programa de Pós-Graduação em Ecologia, Instituto de Biologia, Universidade Federal do Rio de Janeiro; 1999. p.91-138. (Oecologia Brasiliensis; v. 6).

Bush MB. Amazonian speciation: a necessarily complex model. J Biogeogr. 1994; 21(1):5-17.

Cain SA. Foundations of plant geography. New York: Harper \& Brothers Publishers; 1944.

Carvalho TP, Albert JS. The Amazon-Paraguay divide. In: Albert JS, Reis RE, editors. Historical biogeography of Neotropical freshwater fishes. Berkeley, Los Angeles, London: University of California Press; 2011. p.193-202.

Carvalho TP, Bertaco VA. Two new species of Hyphessobrycon (Teleostei: Characidae) from upper rio Tapajós basin on Chapada dos Parecis, Central Brazil. Neotrop Ichthyol. 2006; 4(3):301-08.

Castelnau FL. Poissons. Animaux nouveaux ou rares recueillis pendant l'expédition dans les partes Centrales de l'Amérique du Sud, de Rio de Janeiro a Lima, et de Lima au Pará; exécutée par ordre du gouvernement Français pendant les années 1843 a 1847. Paris: Chez P. Bertrand; 1855. [pt. 7], t.2: pt.1 (1855), Poissons.

Chen W-J, Lavoue S, Mayden RL. Evolutionary origin and early biogeography of otophysan fishes (Ostariophysi: Teleostei). Evolution. 2013; 67(8):2218-39.

Cope ED. Contribution to the ichthyology of the Marañon. Proc Am Philos Soc. 1870; 11(81):559-70.

Crisci JV, Katinas L, Posadas P. Historical biogeography: an introduction. Cambridge: Harvard University Press; 2003.

Croizat L. Panbiogeography or an introductory synthesis of zoogeography, phytogeography, and geology; with notes on evolution, systematics, ecology, anthropology, etc. Caracas: Published by the author; 1958. 
Croizat L. Space, time, form: the biological synthesis. Caracas: Published by the author; 1964.

Croizat L, Nelson G, Rosen DE. Centers of origin and related concepts. Syst Zool. 1974; 23(2):265-87.

Cuvier G. Sur les poissons du sous-genre Mylètes. Mem Mus Natl Hist Nat, Ser A. 1818; 4:444-56.

Cuvier G. Sur les poissons du sous-genre Hydrocyon, sur deux nouvelles espèces de Chalceus, sur trois nouvelles espèces du Serrasalmes, et sur l'Argentina glossodonta de Forskahl, qui est l'Albula gonorhynchus de Bloch. Mem Mus Natl Hist Nat, Ser A. 1819; 5:351-79.

Cuvier G. Le Règne Animal, distribué d'après son organisation, pour servir de base à l'histoire naturelle des animaux et d'introduction à l'anatomie comparée. Paris: Chez Déterville Libraire; 1829.

Cuvier G, Valenciennes A. Histoire Naturelle des Poisons. Paris: Chez P. Bertrand; 1846. t. 18, Suite du livre dix-huitième, Cyprinoïdes. Livre dix-neuvième. Des Ésoces ou Luciö̈des.

Dagosta FCP, Marinho MMF, Benine RC. A new species of Moenkhausia Eigenmann (Characiformes: Characidae) from the upper rio Juruena basin, Central Brazil. Zootaxa. 2015; 4032(4):417-25.

Dagosta FCP, Marinho MMF, Camelier P. A new species of Hyphessobrycon Durbin (Characiformes: Characidae) from the middle rio São Francisco and upper and middle rio Tocantins basins, Brazil, with comments on its biogeographic history. Neotrop Ichthyol. 2014; 12(2):365-75.

Dagosta FCP, de Pinna M. Biogeography of Amazonian fishes: deconstructing river basins as biogeographic units. Neotrop Ichthyol. 2017; 15(3):e170034. Available from: 10.1590/19820224-20170034

Darlington P. Zoogeography: the geographical distribution of animals. New York: John Wilwey \& Sons, Inc.; 1957.

Darwin C. On the origin of species by means of natural selection, or the preservation of favoured races in the struggle for life. London: John Murray; 1859.

Ebach MC, Tangney RS. Biogeography in a changing world. Boca Raton: CRC Press; 2006.

Eigenmann $\mathrm{CH}$. The fresh-water fishes of Patagonia and an examination of the Archiplata-Archhelenis theory. In: Scott, WB, editor. Reports of the Princeton University Expeditions to Patagonia 1896-1899. Princeton: Princeton University; 1909. vol. 3, Zöology, pt. 3; p.293-374.

Eigenmann $\mathrm{CH}$. The Magdalena basin and the horizontal and vertical distribution of its fishes. Indiana Univ Sci Ser. 1920; (7):21-34.

Eigenmann $\mathrm{CH}$. The origin and distribution of the genera of the fishes of South America West of the Maracaibo, Orinoco and Amazon Basins. Proc Am Philos Soc. 1921a; 60(1):1-6.

Eigenmann $\mathrm{CH}$. The nature and origin of the fishes of the Pacific slope of Ecuador, Peru and Chile. Proc Am Philos Soc 1921b; 60(4):503-23.

Eigenmann CH. The fishes of the Pacific slope of South America and the bearing of their distribution on the history of the development of the topography of Peru, Ecuador and Western Colombia. Am Nat. 1923; 57(650):193-210.

Eigenmann CH, Eigenmann RS. A revision of the South American Nematognathi or cat-fishes. Occas Pap Calif Acad Sci. 1890; (1):1-508.

Eigenmann $\mathrm{CH}$, Eigenmann RS. A catalogue of the fresh-water fishes of South America. Proc U S Natl Mus. 1891; 14(842):181.
Endler JA. Problems in distinguishing historical from ecological factors in biogeography. Am Zool. 1982; 22(2):441-52.

Ferraris CJ, Jr. Relationships of the Neotropical catfish genus Nemuroglanis, with a description of a new species (Osteichthyes: Siluriformes: Pimelodidae). Proc Biol Soc Wash. 1988; 101(3):509-16.

Frailey CD, Lavina EL, Rancy A, Souza Filho JP. A proposed Pleistocene/Holocene lake in the Amazon basin and its significance to Amazonian geology and biogeography. Acta Amazon. 1988; 18(3-4):119-43.

Gayet M. Considération sur la phylogénie et la paléobiogéographie des Ostariophysaires. Geobios Mem Spec. 1982; 6:39-52.

George W. Biologist philosopher: a study of the life and writings of Alfred Russel Wallace. London: Abelard-Schuman; 1964.

Géry J. Notes on the ichthyology of Surinam and other Guianas. 10. The distribution pattern of the genus Hemibrycon, with a description of a new species from Surinam and an incursion into ecotaxonomy. Bulletin of Aquatic Biology. 1962; 3(28):65-80.

Géry J. Poissons characoides nouveaux ou non signalés de l'Ilha do Bananal, Brésil. Vie et Milieu. 1964; (S17):447-71.

Géry J. The fresh-water fishes of South America. In: Fittkau EJ, Illies J, Klinge H, Schwabe GH, Sioli, H, editors. Biogeography and ecology in South America. The Hague: Dr. W. Junk N.V.; 1969. p.328-348. (Monographiae Biologicae; 19).

Géry J. The fishes of Amazonia. In: Sioli H, editor. The Amazon: Limnology and landscape ecology of a mighty tropical river and its basin. Dordrecht, Boston, Lancaster: Dr. W. Junk Publishers; 1984. p.353-370.

Gill TN. Synopsis of the fresh water fishes of the western portion of the island of Trinidad, W. I. Ann Lyceum Nat Hist New York. 1858; 6:363-430.

Gosline WA. The problem of the derivation of the South American and African fresh-water fish fauna. An Acad Bras Cienc. 1944; 16(3):211-23.

Goulding M, Barthem R, Ferreira E. The Smithsonian Atlas of the Amazon. Washington (DC): Smithsonian Books; 2003.

Goulding M, Carvalho ML, Ferreira EG. Rio Negro: rich life in poor waters. The Hague: SPB Academic Publishing; 1988.

Günther A. An introduction to the study of fishes. Edinburgh: Adam and Charles Black; 1880.

Haffer J. Speciation in Amazonian forest birds. Science. 1969; 165(3889):131-37.

Haffer J. General aspects of the refuge theory. In: Prance GT, editor. Biological diversification in the tropics. New York: Columbia University Press; 1982. p.6-24.

Haseman JD. Some factors of geographical distribution in South America. Ann N Y Acad Sci. 1912; 22:9-112.

Hennig W. Grundzüge einer Theorie der phylogenetischen Systematik. Berlin: Deutscher Zentralverlag; 1950.

Hennig W. Phylogenetic systematics. Urbana: University of Illinois Press; 1966.

Hubert N, Duponchelle F, Nuñez J, Garcia-Dávila C, Paugy D, Renno JF. Phylogeography of the piranha genera Serrasalmus and Pygocentrus: Implications for the diversification of the Neotropical ichthyofauna. Mol Ecol. 2007; 16(10):2115-36.

Hubert N, Renno JF. Historical biogeography of South American freshwater fishes. J Biogeogr. 2006; 33(8):1414-36.

Humphries CJ, Parenti LR. Cladistic biogeography. Oxford: Oxford University Press; 1986.

Humphries CJ, Parenti LR. Cladistic biogeography: interpreting patterns of plant and animal distributions. 2nd ed. Oxford: Oxford University Press; 1999. (Oxford Biogeography Series; v. 12). 
von Ihering $\mathrm{H}$. On the ancient relations between New Zealand and South America. Trans R Soc N Z. 1891; 24:431-45.

von Ihering $\mathrm{H}$. The history of Neotropical region. Science. 1900(310); 12:857-64.

von Ihering H. Archhelenis und Archinotis. Gesammelte Beitrage zur Geschichte der neotropishen Region. Leipzig: Verlag von Wilhelm Engelmann; 1907.

Ingenito LFS, Lima FCT, Buckup PA. A new species of Hyphessobrycon Durbin (Characiformes: Characidae) from the rio Juruena basin, Central Brazil, with notes on $H$. loweae Costa \& Géry. Neotrop Ichthyol. 2013; 11(1):33-44.

Ivanyisky SJ III, Albert JS. Systematics and biogeography of Sternarchellini (Gymnotiformes: Apteronotidae): Diversification of electric fishes in large Amazonian rivers. Neotrop Ichthyol. 2014; 12(3):565-84.

Jégu M. Influência das Alterações Climáticas do Quaternário sobre a distribuição e evolução dos peixes na Amazônia. Congresso Latino-Americano de Genética: Proceedings Rev Bras Genet. 1992a; 15(1):234-37.

Jégu M. Variations du niveau marin et distribution des poissons d'eau douce en Amazonie Orientale. In: Marie-Thérèse P, editor. Evolution des littoraux de Guyane et de la zone caraïbe méridionale pendant le quaternaire. Paris: ORSTOM; 1992b. p.281-97. (Colloques et Séminaires).

Jégu M, Keith P. Le bas Oyapock limite septentrionale ou simple étape de la progression de la faune des poissons d'Amazonie occidentale. C R Acad Sci, Ser Gen Vie Scie. 1999; 322(12):1133-45.

Jordan DS. The dispersion of fresh-water fishes. In: Jordan DS, editor. Science Sketches. Chicago: A. C. McClurg and Company; 1896. p.83-132.

Kullander SO. Cichlid fishes of the Amazon River drainage of Peru. Swedish Museum of Natural History. 1986; 1-431.

Lima FCT, Birindelli JLO. Moenkhausia petymbuaba, a new species of characid from the Sierra do Cachimbo, Rio Xingu basin, Brazil (Characiformes: Characidae). Ichthyol Explor Freshw. 2006; 17(1):53-58.

Lima FCT, Britski HA, Machado FA. A new Moenkhausia (Characiformes: Characidae) from Central Brazil, with comments on the area relationship between the upper rio Tapajós and upper rio Paraguai systems. Aqua, International Journal of Ichthyology. 2007; 13(2):45-54.

Lima FCT, Ribeiro AC. Continental-scale tectonic controls of biogeography and ecology. In: Albert JS, Reis RE, editors. Historical biogeography of Neotropical freshwater fishes. Berkeley, Los Angeles, London: University of California Press; 2011. p.145-164.

Linnaeus C. Systema Naturae per regna trianaturae, secundum classes, ordines, genera, species, cum characteribus, differentiis, synonymis, locis. Editiodecima, reformata.). Holmiae (Stockholm): Imprensis Laurentii Salvii. 1758; 1:1824. t.1.

Lovejoy NR, Albert JS, Crampton WGR. Miocene marine incursions and marine/freshwater transitions: evidence from Neotropical fishes. J South Am Earth Sci. 2006; 21(1-2):5-13.

Lovejoy NR, Willis SC, Albert JS. Molecular signatures of Neogene biogeographic events in the Amazon fish fauna. In: Hoorn, CM, Wesselingh FP, editors. Amazonia, Landscape and Species Evolution. Oxford, UK: Blackwell Publishing. 2010; p.405-417.

Lundberg JG. African-South American freshwater fish clades and continental drift: problems with a paradigm. In: Goldblatt P, editor. In: Biological relationships between Africa and South America. New Haven: Yale University Press; 1993. p.156-199.

Lundberg JG. Fishes of the La Venta fauna: additional taxa, biotic and paleoenvironmental implications. In: Kay RF, Madden RH, Cifelli RL, Flynn JJ, editors. Vertebrate Paleontology in the Neotropics: The Miocene Fauna of La Venta, Colombia. Washington (DC): Smithsonian Institution Press; 1997. p.67-91.

Lundberg JG. Brachyplatystoma promagdalena, new species, a fossil goliath catfish (Siluriformes: Pimelodidae) from the Miocene of Colombia, South America. Neotrop Ichthyol. 2005; 3(4):597-605.

Lundberg JG, Aguilera O. The late Miocene Phractocephalus catfish (Siluriformes: Pimelodidae) from Urumaco, Venezuela: Additional specimens and reinterpretation as a distinct species. Neotrop Ichthyol. 2003; 1(2):97-109.

Lundberg JG, Chernoff B. A Miocene fossil of the amazonian fish Arapaima (Teleostei, Arapaimidae) from the Magdalena river region of Colombia: Biogeographic and evolutionary implications. Biotropica. 1992; 24(1):2-14.

Lundberg JG, Linares OJ, Antonio ME, Nass P. Phractocephalus hemiliopterus (Pimelodidae, Siluriformes) from the upper Miocene Urumaco Formation, Venezuela: A further case of evolutionary stasis and local extinction among South American fishes. J Vertebr Paleontol. 1988; 8(2):131-38.

Lundberg JG, Machado-Allison A, Kay RF. Miocene characid fishes from Colombia: Evidence for evolutionary stasis and extirpation in the South American ichthyofauna. Science. 1986; 234(4773):208-09.

Lundberg JG, Mago-Leccia F. A review of Rhabdolichops (Gymnotiformes, Sternopygidae), a genus of South American freshwater fishes, with descriptions of four new species. Proc Acad Nat Sci Philadelphia. 1986; 138(1):53-85.

Lundberg JG, Marshall LG, Guerrero J, Horton B, Malabarba MCS, Wesselingh F. The stage for Neotropical fish diversification: a history of tropical South American rivers. In: Malabarba LR, Reis RE, Vari RP, Lucena ZM, Lucena CAS, editors. Phylogeny and Classification of Neotropical Fishes. Porto Alegre: Edipucrs; 1998. p.13-48.

Lundberg JG, Sabaj Pérez MH, Dahdul WM, Aguilera OA. The Amazonian Neogene fish fauna. In: Hoorn C, Wesselingh F, editors. Amazonia: Landscape and species evolution: A look into the past. West Sussex: Wiley-Blackwell; 2010. p.281-301.

Mago-Leccia F, Lundberg JG, Baskin JN. Systematics of the South American freshwater fish genus Adontosternarchus (Gymnotiformes, Apteronotidae). Contributions in Science. 1985; (358):1-19.

Marcgrave G. Historia Naturalis Brasiliae. Auspicio et Beneficio Illustriss. I. Mauritii Com. Nassau... nontantum Plantae et Animalia, sed et Indigenarum morbi, ingenia et mores describuntur et iconibus supra quingentas illustrantur. Lugdun, Batavorum: apud Franciscus Hackiumet Amstelodami: apud Lud. Elzevirium; 1648.

Mariguela TC, Alexandrou MA, Foresti F, Oliveira C. Historical biogeography and cryptic diversity in the Callichthyinae (Siluriformes, Callichthyidae). J Zool Syst Evol Res. 2013; 51(4):308-15.

Marinho MMF, Dagosta FCP, Birindelli JLO. Hemigrammus ataktos: a new species from the rio Tocantins basin, central Brazil (Characiformes: Characidae). Neotrop Ichthyol. 2014; 12(2):257-64.

Mattox GMT, Britz R, Toledo-Piza M, Marinho MMF. Cyanogaster noctivaga, a remarkable new genus and species of miniature fish 
from the Rio Negro, Amazon basin (Ostariophysi: Characidae). Ichthyol Explor Freshw. 2013; 23(4):297-318.

Menezes NA. Systematics and evolution of the tribe Acestrorhynchini (Pisces, Characidae). Arq Zool. 1969; 18(12): $1-150$

Menezes NA. Distribuição e origem da fauna de peixes de água doce das grandes bacias de fluviais do Brasil. In: Branco, SM, organizador. Poluição e Piscicultura. São Paulo: Faculdade de Saúde Pública da USP e Instituto de Pesca; 1972. p.73-78.

Menezes NA. On the Cynopotaminae, a new subfamily of Characidae (Osteichthyes, Ostariophysi, Characoidei). Arq Zool. 1976; 28(2):1-91.

Morrone JJ. Evolutionary biogeography: an integrative approach with case studies. New York: Columbia University Press; 2009.

Myers GS. Fresh-water fishes and West Indian zoogeography. Annu Rep Board Regents Smithson Inst. 1938; 92:339-364.

Myers GS. Amoenitates biologicae: the influence of Louis Agassiz on the ichthyology of Brazil. Rev Bras Biol. 1943; 3(1):127-33.

Myers GS. The Amazon and its fishes. Part 2. The Fishes. Aquar J. 1947; 18(7):13-20, 34.

Myers GS. A brief sketch of the history of ichthyology in America to the year 1850. Copeia. 1964; 1964(1):33-41.

Nakatani M, Miya M, Mabuchi K, Saitoh K, Nishida M. Evolutionary history of Otophysi (Teleostei), a major clade of the modern freshwater fishes: Pangaean origin and Mesozoic radiation. BMC Evol Biol. 2011; 11:177.

Nelson G. From Candolle to Croizat: Comments on the history of biogeography. J Hist Biol. 1978; 11(2):296-305.

Nelson G, Platnick N. Systematics and biogeography: cladistics and vicariance. New York: Columbia University Press; 1981.

Nelson O, Rosen DE. Vicariance biogeography: a critique. New York: Columbia University Press; 1979.

Netto-Ferreira AL, Birindelli JLO, Sousa LM, Mariguela TC, Oliveira C. A new miniature characid (Ostariophysi: Characiformes: Characidae), with phylogenetic position inferred from morphological and molecular data. PLoS ONE. 2013; 8(1): e52098.

Novacek MJ, Marshall LG. Early biogeographic history of ostariophysan fishes. Copeia. 1976; 1976(1):1-12.

Ohara WM, Lima FCT. Hyphessobrycon lucenorum (Characiformes: Characidae), a new species from the rio Madeira basin, Rondônia State, Brazil. Zootaxa. 2015; 3972(4):562-72.

Ota RP, Lima FCT, Pavanelli CS. A new species of Hemigrammus Gill, 1858 (Characiformes: Characidae) from the rio Madeira and rio Paraguai basins, with a redescription of H. lunatus. Neotrop Ichthyol. 2014; 12(2):265-79.

Papavero N, Llorente-Bousquets J, Espinosa-Organista D. Historia de la biología comparada desde el génesis hasta el siglo de las luces. Ciudad de México: Universidad Nacional Autónoma de México; 1995. vol. 1, Del génesis a la caída del imperio romano de occidente.

Papavero N, Teixeira DM, Overal WL, Pujol-Luz JR. O Novo Éden: A fauna da Amazônia brasileira nos relatos de viajantes e cronistas desde a descoberta do Rio Amazonas por Pinzón (1500) até o Tratado de Santo Ildefonso (1777). Belém: Museu Paraense Emilio Goeldi; 2000. (Coleção Alexandre Rodrigues Ferreira).

Papavero N, Teixeira DM, Overal WL, Pujol-Luz JR. O Novo Éden. História da Amazônia brasileira nos relatos de viajantes e cronistas desde a descoberta do Rio Amazonas por Pinzón (1500) até o Tratado de Santo Ildefonso (1777): Com transcrição dos principais textos. Segunda Edição, revista e ampliada. Belém: Museu Paraense Emilio Goeldi; 2002. (Coleção Alexandre Rodrigues Ferreira).

Papavero N, Teixeira DM, Pujol-Luz JR. A fauna da Amazônia brasileira nos relatos de viajantes e cronistas dos Séculos XVI ao XVIII. 2. A viagem de Orellana Rio Amazonas abaixo nos anos de 1541 e 1542 e a crônica de Frei Gaspar de Carvajal. Contribuições Avulsas sobre a História Natural do Brasil. 1999; 8:1-6.

Parenti LR, Ebach MC. Comparative biogeography: discovering and classifying biogeographical patterns of a dynamic. Berkeley: University of California Press; 2009.

Pastana MNL, Dagosta FCP. Moenkhausia rubra, a new species from rio Juruena, upper rio Tapajós basin, Brazil (Characiformes: Characidae). Neotrop Ichthyol. 2014. 12(2):389-96.

Pearson NE. The fishes of the Beni-Mamoré and Paraguay basin, and a discussion of the origin of the Paraguayan fauna. Proc Calif Acad Sci. 1937; 23(4):99-114.

Pereira RFM. A ictiologia na Amazônia brasileira de Diogo Nunes (1538) a Landi (1772): a visão dos viajantes e naturalistas que trataram de sua ictiofauna durante este período. [Msc Dissertation]. Belém: Museu Paraense Emilio Goeldi, Universidade Federal do Pará; 2003.

Platnick NI. Concepts of dispersal in historical biogeography. Syst Zool. 1976; 25(3): 294-95.

Prance GT. Biological Diversification in the Tropics. New York: Columbia University Press; 1982.

Regan CT. The distribution of the fishes of the order Ostariophysi. Bijdr Dierkd. 1922; 22(1):203-08.

Ribeiro AC. Tectonic history and the biogeography of the freshwater fishes from the coastal drainages of eastern Brazil: an example of faunal evolution associated with a divergent continental margin. Neotrop Ichthyol. 2006; 4(2):225-46.

Ribeiro AC, Jacob RM, Silva RRSR, Lima FCT, Ferreira DC, Ferreira KM, Mariguela TC, Pereira LH, Oliveira C. Distributions and phylogeographic data of rheophilic freshwater fishes provide evidences on the geographic extension of a central-brazilian amazonian palaeoplateau in the area of the present day Pantanal Wetland. Neotrop Ichthyol. 2013; 11(2):319-26.

Ribeiro AC, Lima FCT, Menezes NA. Biogeografia dos peixes de água doce da América do Sul. In: Carvalho CJB, Almeida EAB, editors. Biogeografia da América do Sul: Padrões e Processos. São Paulo: Editora Roca; 2011. p.261-276.

Ribeiro AC, Menezes NA. Phylogenetic relationships of the species and biogeography of the characid genus Oligosarcus Günther. 1864 (Ostariophysi, Characiformes, Characidae). Zootaxa. 2015; 3949(1):41-81.

Riddle BR. Is biogeography emerging from its identity crisis? J Biogeogr. 2005; 32(2):185-86.

Roberts TR. Ecology of fishes in the Amazon and Congo Basins. Bull Mus Comp Zool. 1972; 143(2):117-47.

Roberts TR. Characoid fish teeth from Miocene deposits in the Cuenca Basin, Ecuador. J Zool. 1975; 175(2):259-71.

Rodríguez-Olarte D, Mojica Corso JI, Taphorn DC. Northern South America: Magdalena and Maracaibo basins. In: Albert JS, Reis RE, editors. Historical biogeography of Neotropical freshwater fishes. Berkely, Los Angeles, London: University of California Press; 2011. p.243-257.

Rosen DE. A vicariance model of Caribbean biogeography. Syst Zool. 1976; 24(4):431-64.

Rosen DE. Vicariant patterns and historical explanation in biogeography. Syst Zool. 1978; 27(2):159-88. 
Rosen DE. Fishes from the upland and intermontane basins of Guatemala: revisionary studies and comparative geography. Bull Am Mus Nat Hist. 1979; 162:267-376.

Roxo FF, Albert JS, Silva GSC, Zawadzki CH, Foresti F, Oliveira C. Molecular phylogeny and biogeographic history of the armored Neotropical catfish subfamilies Hypoptopomatinae, Neoplecostominae and Otothyrinae (Siluriformes: Loricariidae). PLoS ONE. 2014; 9(8):e105564.

Sabaj Pérez MH, Aguilera OAS, Lundberg JG. Fossil catfishes of the families Doradidae and Pimelodidae (Teleostei: Siluriformes) from the Miocene Urumaco Formation of Venezuela. Proc Acad Nat Sci Philadelphia. 2007; 156:157-94.

Saint-Paul U, Zuanon JA, Villacorta Correa MA, Garcia M, Fabré NN, Berger U, Junk WJ. Fish communities in central Amazonian white- and blackwater floodplains. Environ Biol Fishes. 2000; 57(3):235-50.

Salcedo NJ, Rodriguez D, Strauss RE, Baker RJ. The Fitzcarrald Arch: A vicariant event for Chaetostoma (Siluriformes: Loricariidae) speciation? Copeia. 2011; 2011(4):503-12.

Schaefer S. The Andes: Riding the Tectonic Uplift. In: Albert JS, Reis RE, editors. Historical biogeography of Neotropical freshwater fishes. Berkely, Los Angeles, London: University of California Press; 2011. p.259-278.

Shibatta OA, Pavanelli CS. Description of a new Batrochoglanis species (Siluriformes, Pseudopimelodidae) from the rio Paraguai basin, State of Mato Grosso, Brazil. Zootaxa. 2005; 1092(1):21-30.

Silva GSC, Roxo FF, Britzke R, Oliveira C. New species of the Pseudancistrus barbatus group (Siluriformes, Loricariidae) with comments on its biogeography and dispersal routes. ZooKeys. 2014; 406:1-23.

Simpson GG. Evolution and geography: An essay on historical biogeography with special reference to mammals. Eugene: Oregon State University of Higher Education; 1953. (Condon lectures).

Slobodian V, Bockmann FA. A new Brachyrhamdia (Siluriformes: Heptapteridae) from Rio Japurá basin, Brazil, with comments on its phylogenetic affinities, biogeography and mimicry in the genus. Zootaxa. 2013; 3717(1):1-22.

Sousa LM, Netto-Ferreira AL, Birindelli JLO. Two new species of Moenkhausia Eigenmann (Characiformes: Characidae) from Serra do Cachimbo, Pará, Northern Brazil. Neotrop Ichthyol. 2010; 8(2):255-64

Spix JB Von, Agassiz L. Selecta genera et species piscium quos in itinere per Brasiliam Annis MDCCCXVII-MDCCCXX jussu et auspiciis Maximiliani Josephi I. Monachii: Typis Wolf; 1829-31. Pt 1, i-xvi + i-ii + 1-82, Pt 2, 83-138..

Stewart DJ. A review of the South American catfish tribe Hoplomyzontini (Pisces, Aspredinidae), with descriptions of new species from Ecuador. Fieldiana, Zool. 1985; (25):1-19.

Stewart DJ. Revision of Pimelodina and description of a new genus and species from the Peruvian Amazon (Pisces: Pimelodidae). Copeia. 1986; 1986(3):653-67.

Vanzolini PE. A contribuição Zoológica dos primeiros naturalistas viajantes no Brasil. Revista USP. 1996; (30):190-238.

Vari RP. Notes on the characoid subfamily Iguanodectinae, with a description of a new species. Am Mus Novit. 1977; (2612):1-6.

Vari RP. Systematics of the Neotropical characoid genus Curimatopsis (Pisces: Characoidei). Washington (DC): Smithsonian Institution Press; 1982. (Smithsonian Contributions to Zoology; No. 373).

Vari RP. Systematics of the Neotropical characiform genus Potamorhina (Pisces: Characiformes). Washington (DC):
Smithsonian Institution Press; 1984. (Smithsonian Contributions to Zoology; No. 400).

Vari RP. The curimatidae, a lowland Neotropical fish family (Pisces: Characiformes): distribution, endemism, and phylogenetic biogeography. In: Vanzolini PE, Heyer WR, editors. Proceedings of a work-shop on Neotropical distribution patterns. Rio de Janeiro: Academia Brasileira de Ciências; 1988. p.343-377.

Vari RP. Systematics of the Neotropical characiform genus Pseudocurimata Fernández-Yépez (Pisces: Ostariophysi). Washington (DC): Smithsonian Institution Press; 1989a. (Smithsonian Contributions to Zoology; No. 490).

Vari RP. Systematics of the Neotropical characiform genus Curimata Bosc (Pisces: Characiformes). Washington (DC): Smithsonian Institution Press; 1989b. (Smithsonian Contributions to Zoology; No. 474).

Vari RP. Systematics of the Neotropical characiform genus Psectrogaster Eigenmann and Eigenmann (Pisces: Characiformes). Washington (DC): Smithsonian Institution Press; 1989c. (Smithsonian Contributions to Zoology; No. 481).

Vari RP. A phylogenetic study of the Neotropical characiform family Curimatidae (Pisces: Ostariophysi). Washington (DC): Smithsonian Institution Press; 1989d. (Smithsonian Contributions to Zoology; No. 471).

Vari RP. Systematics of the Neotropical characiform genus Steindachnerina Fowler (Pisces: Ostariophysi). Washington (DC): Smithsonian Institution Press; 1991. (Smithsonian Contributions to Zoology; No. 507).

Vari RP. Systematics of the Neotropical Characiform genus Cyphocharax Fowler (Pisces: Ostariophysi). Washington (DC): Smithsonian Institution Press; 1992a. (Smithsonian Contributions to Zoology; No. 529).

Vari RP. Systematics of the Neotropical characiform genus Curimatella Eigenmann and Eigenmann (Pisces: Ostariophysi), with summary comments on the Curimatidae. Washington (DC): Smithsonian Institution Press; 1992b. (Smithsonian Contributions to Zoology; No. 533).

Vari RP, Weitzman SH. A review of the phylogenetic biogeography of the freshwater fishes of South America. In: Peters G, Hutterer R, editors. Vertebrates in the Tropics. Proceedings of the International Symposium on Vertebrate Biogeography and Systematics in the Tropics. Bonn: Alexander Koenig Zoological Research Institute and Zoological Museum; 1989. p.381-393.

Wallace AR. On the monkeys of the Amazon. Proc Zool Soc London. 1852; 20: 107-10.

Wallace, AR. A narrative of travels on the Amazon and Rio Negro. London: Reeve \& Co.; 1853.

Wallace AR. The geographical distribution of animals: with a study of the relations of living and extinct faunas as elucidating the past changes of the Earth's surface. New York: Harper \& Brothers, Publishers; 1876.

Wallace AR. A narrative of travels on the Amazon and Rio Negro: with an account of the native tribes, and observations on the climate, geology, and natural history of the Amazon valley. London, New York, Melbourne: Ward, Lock \& Co; 1889.

Wegener A. Die Entstehung der Kontinente und Ozeane. Geol Rundsch. 1912; 3:276-92.

Weitzman SH, Fink SV. Xenurobryconin phylogeny and putative pheromone pumps in glandulocaudine fishes (Teleostei: Characidae). Washington (DC): Smithsonian Institution Press; 1985. (Smithsonian Contributions to Zoology; No. 421). 
Weitzman SH, Weitzman MJ. Biogeography and evolutionary diversification in Neotropical freshwater fishes, with comments on the Refugia theory. In: Prance GT, editor. Biological Diversification in the Tropics. New York: Columbia University Press; 1982. p.403-422.

Williams DM, Ebach MC. Foundations of systematics and biogeography. New York: Springer Science, Business Media; 2008.

Winemiller KO, Willis SC. The Vaupes Arch and Casiquiare Canal: barriers and passages. In: Albert JS, Reis RE, editors. Historical biogeography of Neotropical freshwater fishes. Berkeley, Los Angeles, London: University of California Press; 2011. p.225242.

(c) (i)

Submitted February 28, 2018

Accepted July 17, 2018 by Marcelo Britto 